\title{
Turning landscape rambles into integrative, interdisciplinary, intergenerational field experiences
}

\section{Tim Lutz LeeAnn Srogi}

Earth \& Space Sciences West Chester University

"The major problems of the world are the result of the difference between how nature works and the way people think." - Gregory Bateson 


\section{Naturalist Guided}

\section{Walk}

FALL 2015

HARMONY HiLl NATURE AREA hike led by GEOLOGIST TIM LUTZ, PH.D

SUNDAY, NOVEMBER 8, 2015

2:00 P.M.

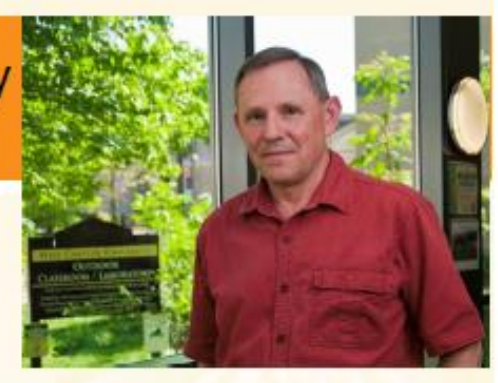

HARMONY HILL NATURE AREA

1200 Skelp Level Road, Downingtown, 19335

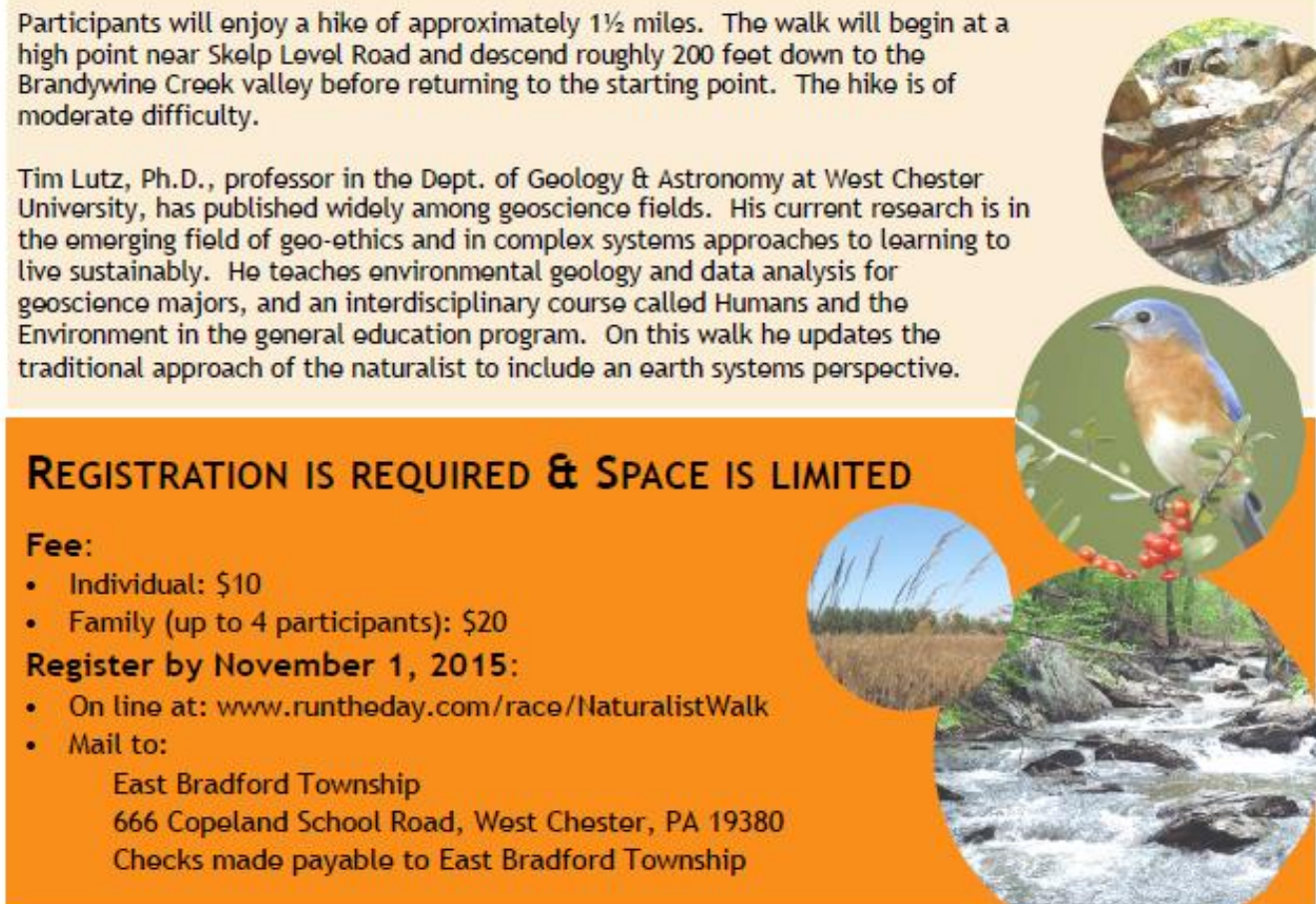

Participants will enjoy a hike of approximately $1 \frac{1}{2}$ miles. The walk will begin at high point near skelp Lovel Road and descend roughly 200 feet down to the moderate difficulty.

Tim Lutz, Ph. D., professor in the Dept. of Geology 政

REGISTRATION IS REQUIRED \& SPACE IS LIMITED

Register by November 1, 2015:

On line at: www.runtheday.com/race/NaturalistWalk
November 2015 - Lutz (and Srogi) led a "Naturalist's Walk" by E Bradford Township

November 2017 - Srogi (and Lutz) led a "Geologist's Walk" for Natural Lands 


\section{Naturalist Guided}

\section{Walk FaLL 2015}

Natural

Vlrs Lands

visit what we do events

\section{Geology Rocks! - SOLD OUT}

Fulshaw Craeg Preserve I Sat, November 04, 2017, 9:00am -

11:00am

Event is SOLD OUT! Check out our other events to plan your next adventure outside!

From ringing rocks to boulders once quarried for Philadelphia streets, Natural Lands' Fulshaw Craeg Preserve features an array of geological wonders. Steep, rocky slopes and a winding stream were natural limitations to agriculture and development, leaving this land virtually untouched by humans.

Expert geologists guide a fascinating exploration of this special spot in Montgomery County. We'll trek stony trails, examine outcroppings, and discuss natural and cultural facets.
November 2015 - Lutz (and Srogi) led a "Naturalist's Walk" by E Bradford Township

November 2017 - Srogi (and Lutz) led a "Geologist's Walk" for Natural Lands 


\section{Naturalist Guided} Walk

FALL 2015

Natural

Lands

visit what we do events

\section{Geology Rocks! - SOLD OUT}

Fulshaw Craeg Preserve I Sat, November 04, 2017, 9:00am -

11:00am

Event is SOLD OUT! Check out our other events to plan your next adventure outside!

From ringing rocks to boulders once quarried for Philadelphia streets, Natural Lands' Fulshaw Craeg Preserve features an array of geological wonders. Steep, rocky slopes and a winding stream were natural limitations to agriculture and development, leaving this land virtually untouched by humans.

Expert geologists guide a fascinating exploration of this special spot in Montgomery County. We'll trek stony trails, examine outcroppings, and discuss natural and cultural facets.
November 2015 - Lutz (and Srogi) led a "Naturalist's Walk" by E Bradford Township

November 2017 - Srogi (and Lutz) led a "Geologist's Walk" for Natural Lands

What is a "Naturalist's Walk?" What is a "Geologist's Walk?"

Outline of this talk:

- Conceptualization

- Preparation

- The Walks 


\section{CONCEPTUALIZATION}

\section{Audience expectations}

Naturalist's walk: nature

birds, plants, trees, maybe soil, maybe streams

"we were surprised to have a geologist leading this walk!"

\section{Geologist's walk: geology}

rocks, minerals, rocks, maybe streams, maybe soils, rocks 


\section{CONCEPTUALIZATION}

\section{Audience expectations}

Naturalist's walk: nature

birds, plants, trees, maybe soil, maybe streams

"we were surprised to have a geologist leading this walk!"

\section{Geologist's walk: geology}

rocks, minerals, rocks, maybe streams, maybe soils, rocks

In the end both walks were more similar than they were different

The similarities came from our conceptualizations of nature and geology

The differences emerged from the different locations of the walks 
"The basic principles of ecology - interdependence, the cyclical nature of ecological processes, flexibility, diversity, etc. - are basic systemic properties of all living systems. This is why the systemic understanding of life [systems thinking] not only holds great intellectual fascination but is also tremendously important from a practical point of view. It is the cognitive foundation of our endeavor to move toward a sustainable future."

Capra, F. \& Luisi, P.L., 2016, The systems view of life: a unifying vision (Cambridge University Press)

Systems Thinking - everything is connected so focus on relationships and interdependence not isolated parts

Human processes and effects are integrated into the interconnected, interdependent landscape so human history is part of the "naturalist's" conceptualization 
The landscape we live in is the landscape at one point in time.

It didn't always look like this!

Again, human history is part of the "naturalist's" conceptualization.

Geologists bring the ability to travel back before human time into deep time.

We can help everyone use clues in nature and their imaginations to "see" ancient landscapes change into the world around them today.

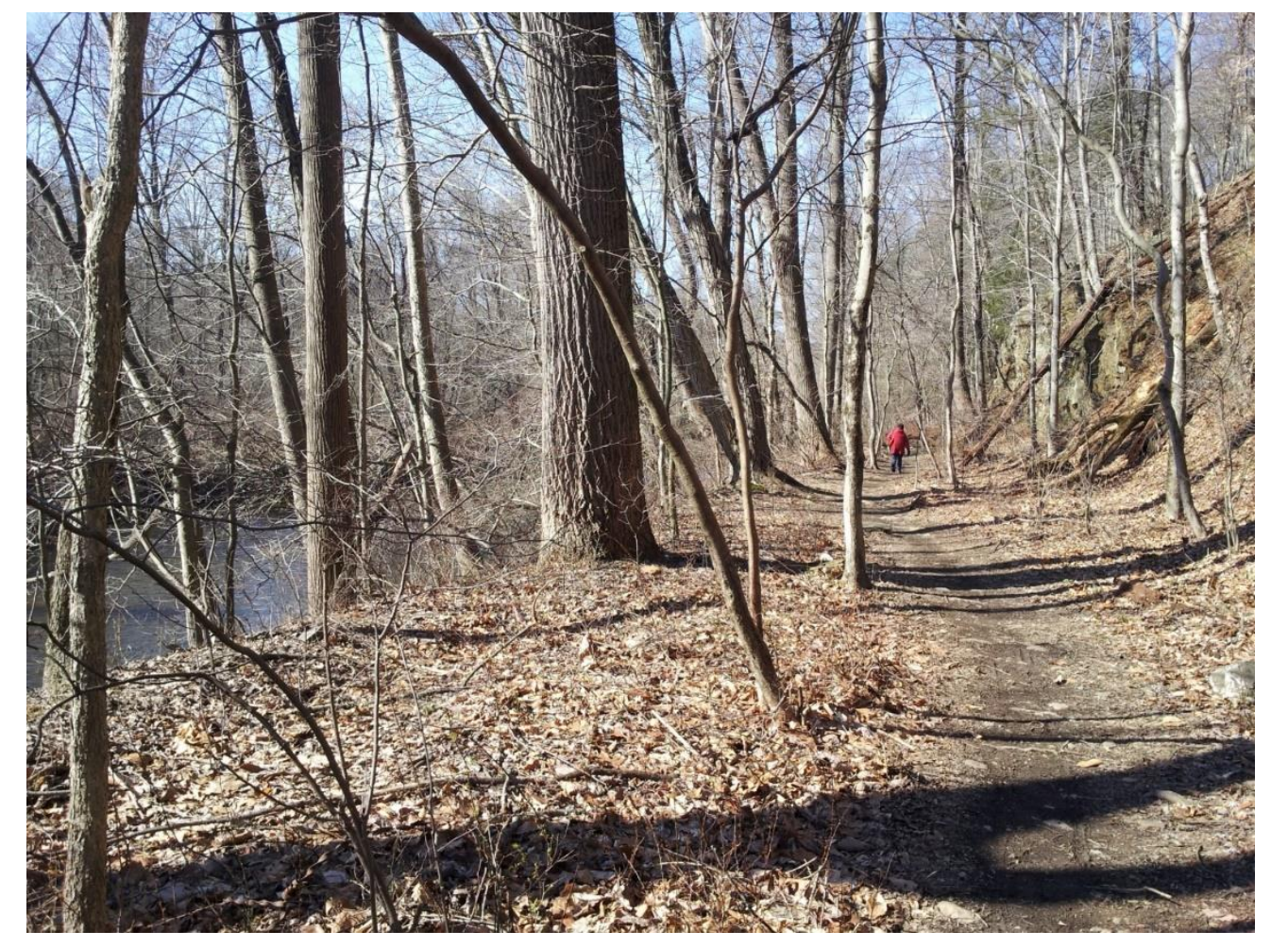

The trail today was a trolley line until 1929 
Fulshaw Craeg Stewardship Plan by

\section{OUR CONCEPTUALIZATION}

"The major problems of the world are the result of the difference between how nature works and the way people think." - Gregory Bateson

The nature we talk about in the classroom and write about in reports is far different from nature experienced on a walk in the woods.

The classroom and the report reflect how people think. We apply a disciplinary and reductionist approach to develop and present the content in a linear manner. Each slide or section neatly separates one concept from the next; carefully chosen images illustrate each point in turn; everything is known in advance, from beginning to end.
Natural Lands

II. Natural Resources

Geology

Soils

Topography and Slopes

Hydrology

Plant Resources

Wildlife

Special Features

Stewardship Issues

III. Cultural and Historic Resources Historic and Archaeological Features Existing Improvements

Public Use Facilities

IV. Preserve Stewardship

Stewardship Units

Conservation Values and Priorities

Stewardship Goals 


\section{OUR Conceptualization}

On a walk in the woods, we are brought into contact with a world entirely whole and undivided.

Natural and human systems of all kinds and scales intertwine and interact.

Time is elastic, from the immediate murmur of a flowing stream, to the shape of its valley, to the age of the rocks that underlie it.

What will be happening the day of the walk is unknown. The walk is an open-ended adventure.

\section{Fulshaw Craeg Preserve}

Stewardship Plan

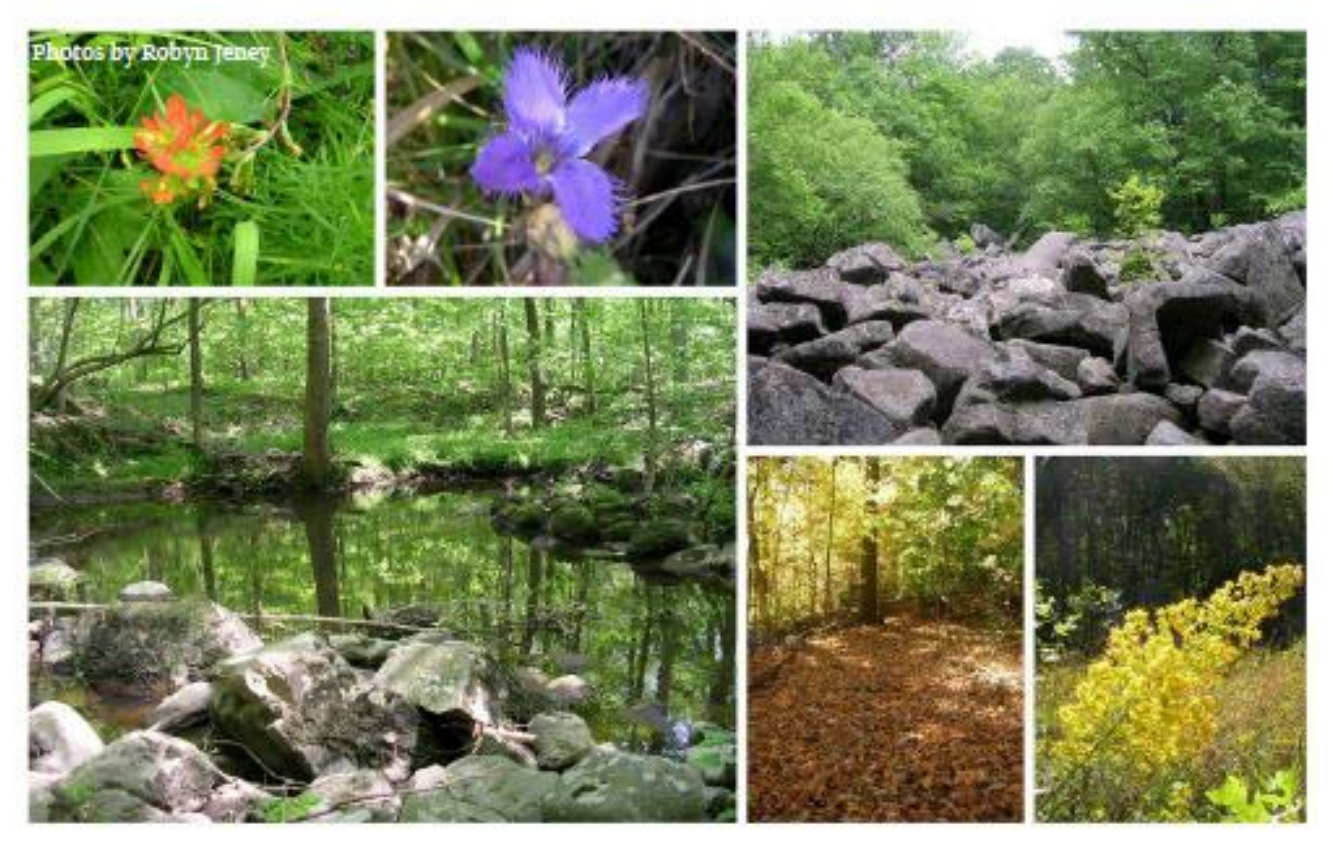

Montgomery County, PA

December 2008 


\section{From Conceptualization to Preparation}

The classroom is a reflection of how people think. We apply a disciplinary and reductionist approach to develop and present the content in a linear manner. Each slide neatly separates one concept from the next; carefully chosen images illustrate each point in turn; everything is known in advance, from beginning to end.

On a walk in the woods, we are brought into contact with a world entirely whole and undivided. Natural and human systems of all kinds and scales intertwine and interact. Time is elastic, from the immediate murmur of a flowing stream, to the shape of its valley, to the age of the rocks that underlie it. What will be happening the day of the walk is unknown. The walk is an open-ended adventure. 


\section{Preparation}

Working with local government or organizations

Anticipating the audience who will be the participants?
Naturalist Guided Walk

FALL 2015

HaRMONy Hill NatURe AREa hike led by GEOLOGIST TIM LUTZ, PH.D

SUNDAY, NOVEMBER 8, 2015

$$
\text { 2:00 P.M. }
$$

HARMONY HILL NATURE AREA

1200 Skelp Level Road, Downingtown, 19335

Participants will enjoy a hike of approximately $1 \frac{1}{2}$ miles. The walk will begin at a high point near Skelp Level Road and descend roughly 200 feet down to the
Brandywine Creek valley before returning to the starting point. The hike is of moderate difficulty.

Tim Lutz, Ph.D., professor in the Dept. of Geology \& Astronomy at West Chester University, has published widely among geoscience fields. His current research is in the emerging field of geo-ethics and in complex systems approaches to learning to live sustainably. He teaches environmental geology and data analysis for geoscience majors, and an interdisciplinary course called Humans and the Envronment in the general education program. On this walk ho updates the traditional approach of the naturalist to include an earth systems perspective.

REGISTRATION IS REQUIRED \& SPACE IS LIMITED

Fee:

- Individual: $\$ 10$

- Family (up to 4 participants): $\$ 20$

Register by November 1,2015 :

On line at: unmwruntheday.com/race/NaturalistWalk

Mail to:

East Bradford Township

666 Copeland School Road, West Chester, PA 19380 Checks made payable to East Bradford Township
Registrant

characteristics

\begin{tabular}{|c|c|}
\hline Gender & Age \\
\hline Male & 4 \\
\hline Female & 11 \\
\hline Female & 15 \\
\hline Female & 20 \\
\hline Male & 33 \\
\hline Female & 44 \\
\hline Male & 45 \\
\hline Male & 45 \\
\hline Male & 48 \\
\hline Female & 50 \\
\hline Male & 52 \\
\hline Male & 53 \\
\hline Female & 57 \\
\hline Male & 63 \\
\hline Male & 63 \\
\hline Female & 64 \\
\hline Female & 64 \\
\hline Male & 64 \\
\hline Female & 65 \\
\hline Male & 69 \\
\hline Female & 71 \\
\hline Male & 73 \\
\hline Male & 78 \\
\hline Female & 80 \\
\hline
\end{tabular}




\section{Preparation -}

ANTICIPATING THE AUDIENCE

Though not employed overtly during the walks, values of nature provide a framework to help the guides acknowledge, engage and respond to values the participants express during the walk.

- Kellert, S.R., 1996, The value of life: biological diversity and human society (Island Press)

- Lutz, T. \& Srogi, L., 2010, A values framework for students to develop thoughtful attitudes about citizenship and stewardship (Journal of

Geoscience Education, v. 58, p. 14-20)

\begin{tabular}{|c|l|}
\hline Value & \multicolumn{1}{|c|}{ Brief definition } \\
\hline Ecologistic/scientific & $\begin{array}{l}\text { Systematic study of structure, function, } \\
\text { and relationship in nature }\end{array}$ \\
\hline Utilitarian & $\begin{array}{l}\text { Practical and material exploitation of } \\
\text { nature }\end{array}$ \\
\hline Naturalistic & $\begin{array}{l}\text { Direct experience and exploration of } \\
\text { nature }\end{array}$ \\
\hline Aesthetic & Physical appeal and beauty of nature \\
\hline Symbolic & Use of nature for language and thought \\
\hline Humanistic & $\begin{array}{l}\text { Strong emotional attachment and love for } \\
\text { aspects of nature }\end{array}$ \\
\hline Moralistic & $\begin{array}{l}\text { Spiritual reverence and ethical concern } \\
\text { for nature }\end{array}$ \\
\hline Dominionistic & $\begin{array}{l}\text { Mastery, physical control, dominance of } \\
\text { nature }\end{array}$ \\
\hline Negativistic & Fear, aversion, alienation from nature \\
\hline Theistic & $\begin{array}{l}\text { Nature reflects the will of supernatural } \\
\text { forces or deities }\end{array}$ \\
\hline
\end{tabular}




\section{Preparation - to the field!}

What features best illustrate Systems Thinking and Time Travel?

What will spark the participants' imaginations?

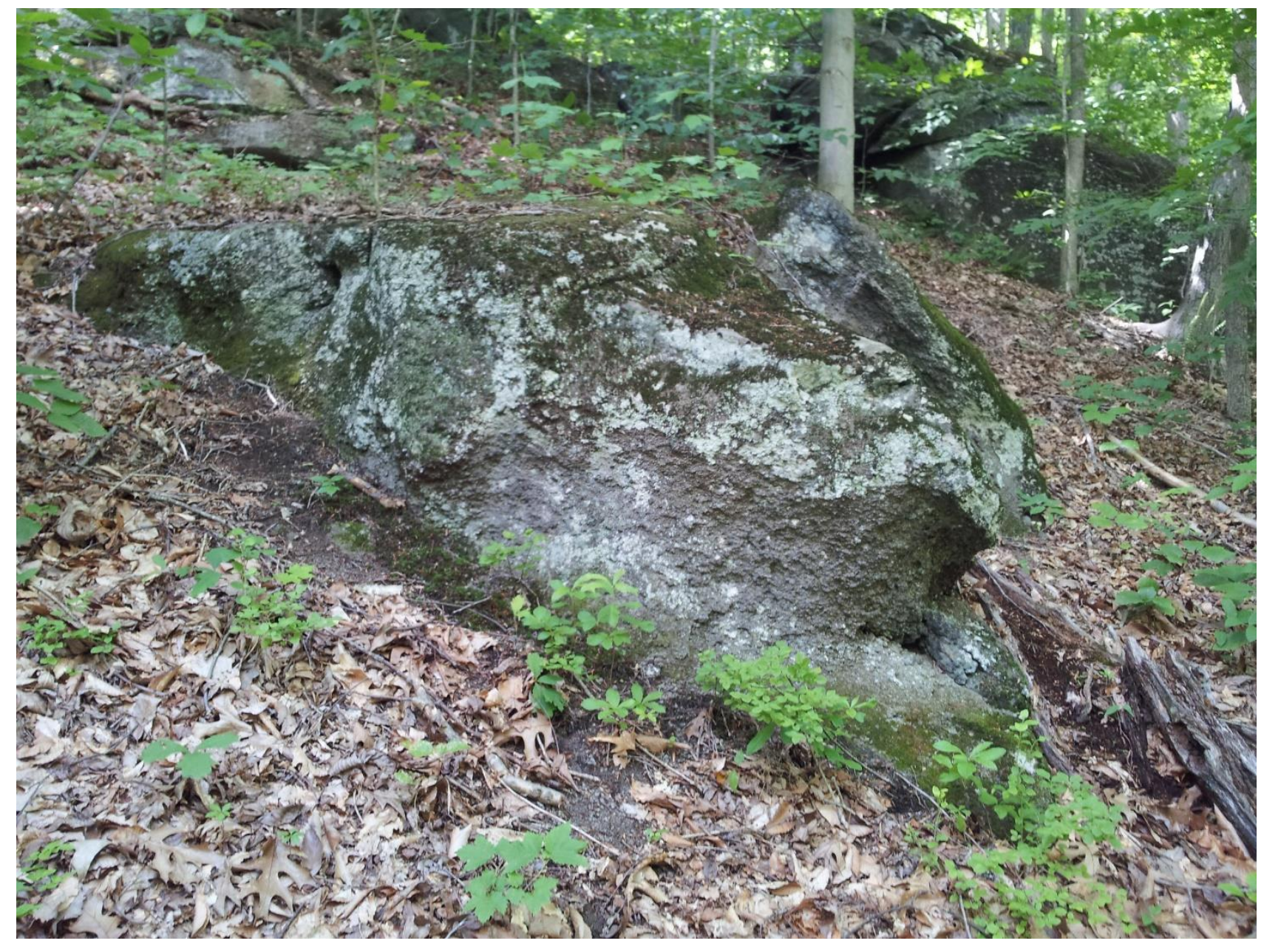

170730

With $T$ to Fulshew Crege Preserve (Nutlond)

Wolked entrame trit to creck

- treled with Line Daris, wildflowers

Mearured new trail to wire crossingt rew trail

that frelsur $~$ prablelt close to creeh

- tacked with Tom, resident, t doy Zaas

Reached intersaction with mapped trail thet goes

uhill. Big rock just bezad intersection

(1) - cumblate diabos, big ox

(2) periglaciel cracles on swaces - crascuts rode - knobbly weethering-not individual $x / 5$

3/-curving fractures - corliy or spherient weathing

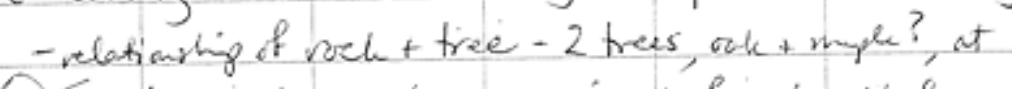

(4) either end; also tras growing at of sphervidal weathin contrets an top; maph (?) has yellew-billied sopscher marks - 5

3) ardishe see onim- tike layes of Ephasidel weathing

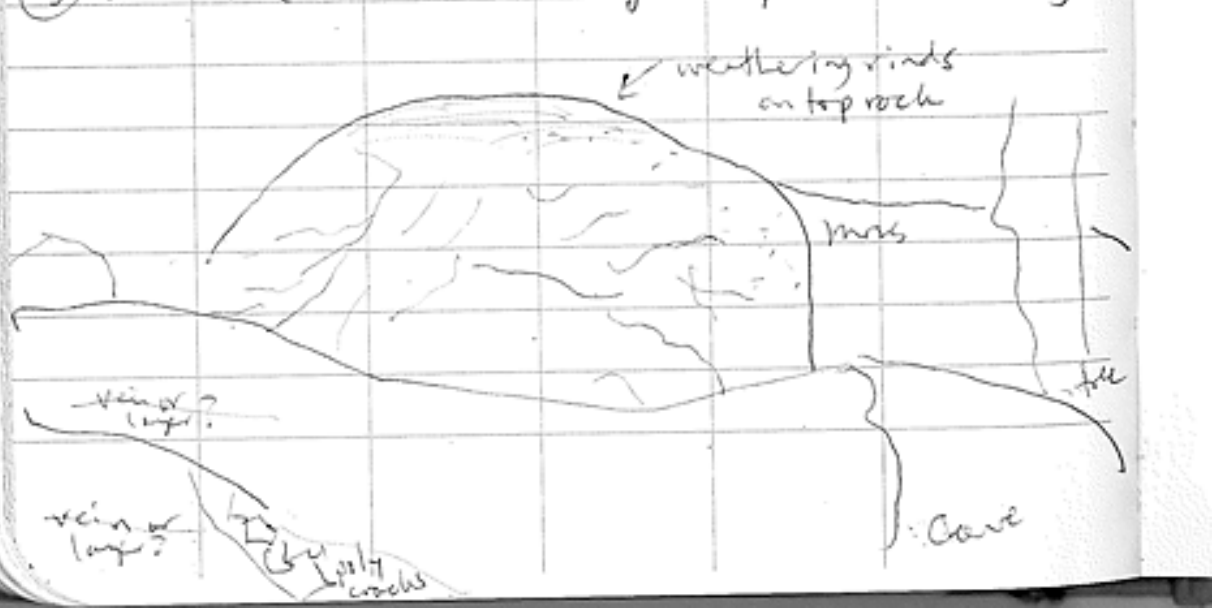




\section{Preparation - Maps and Images of Landscape}

Currently this is a re-growth forest with a small river (East Branch of Brandywine Creek) and tributaries

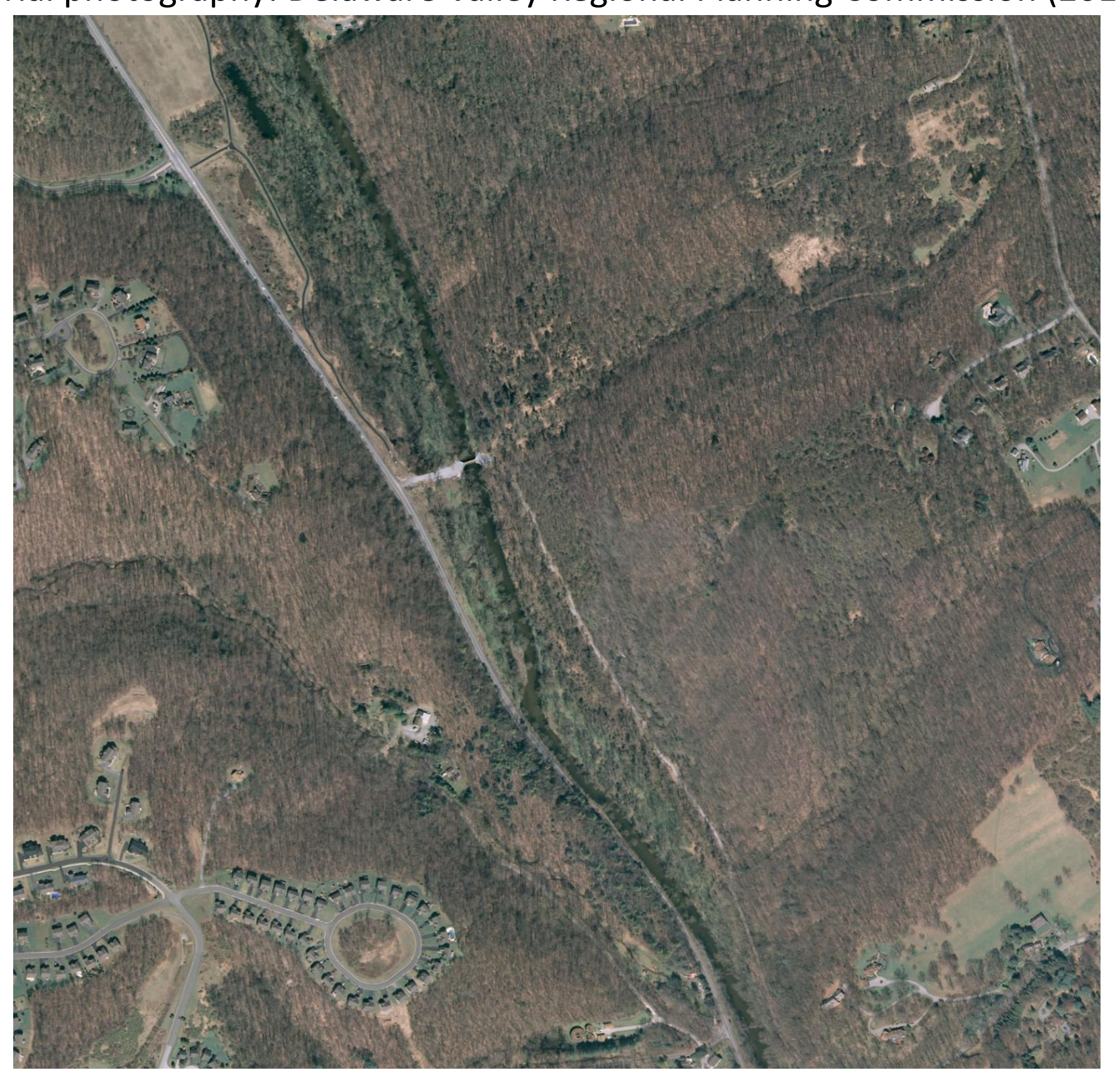



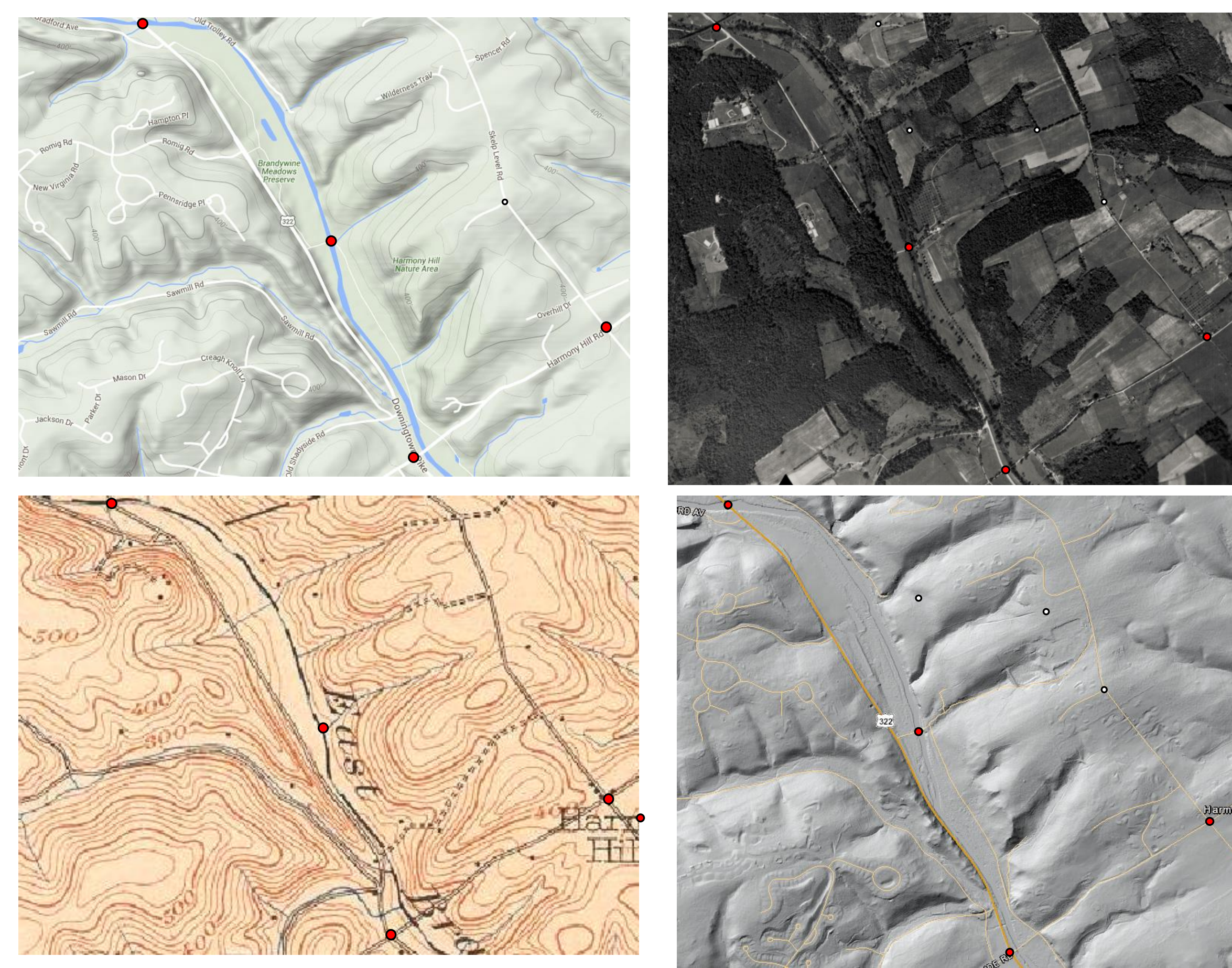

\section{Preparation}

Exploring Maps and Images to Reveal Changing Landscapes over Human History

What is the best image to communicate changing landscape to our participants?

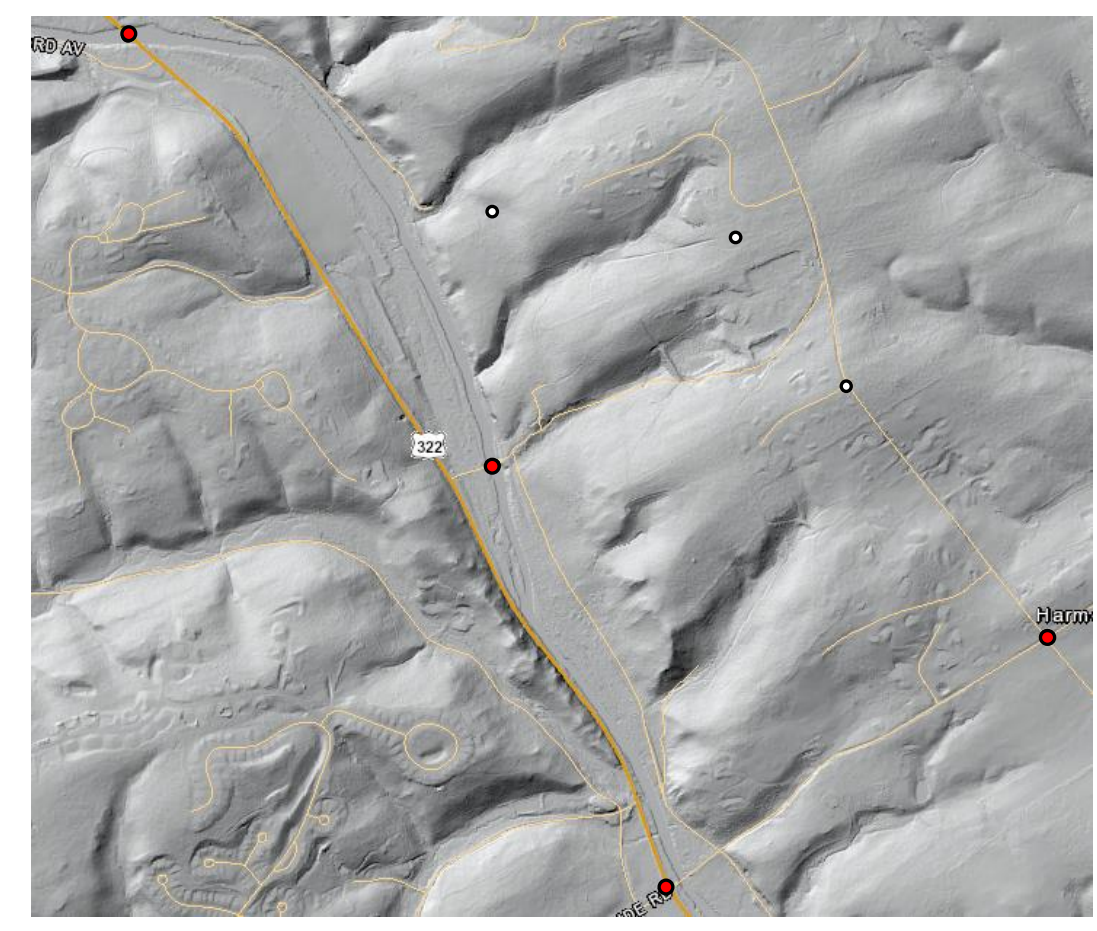




\section{Harmony Hill Natural Area trails on 1937 aerial photo}

\section{Preparation}

This is the map we provided to participants on the walk to connect modern trail system to human land uses in the past

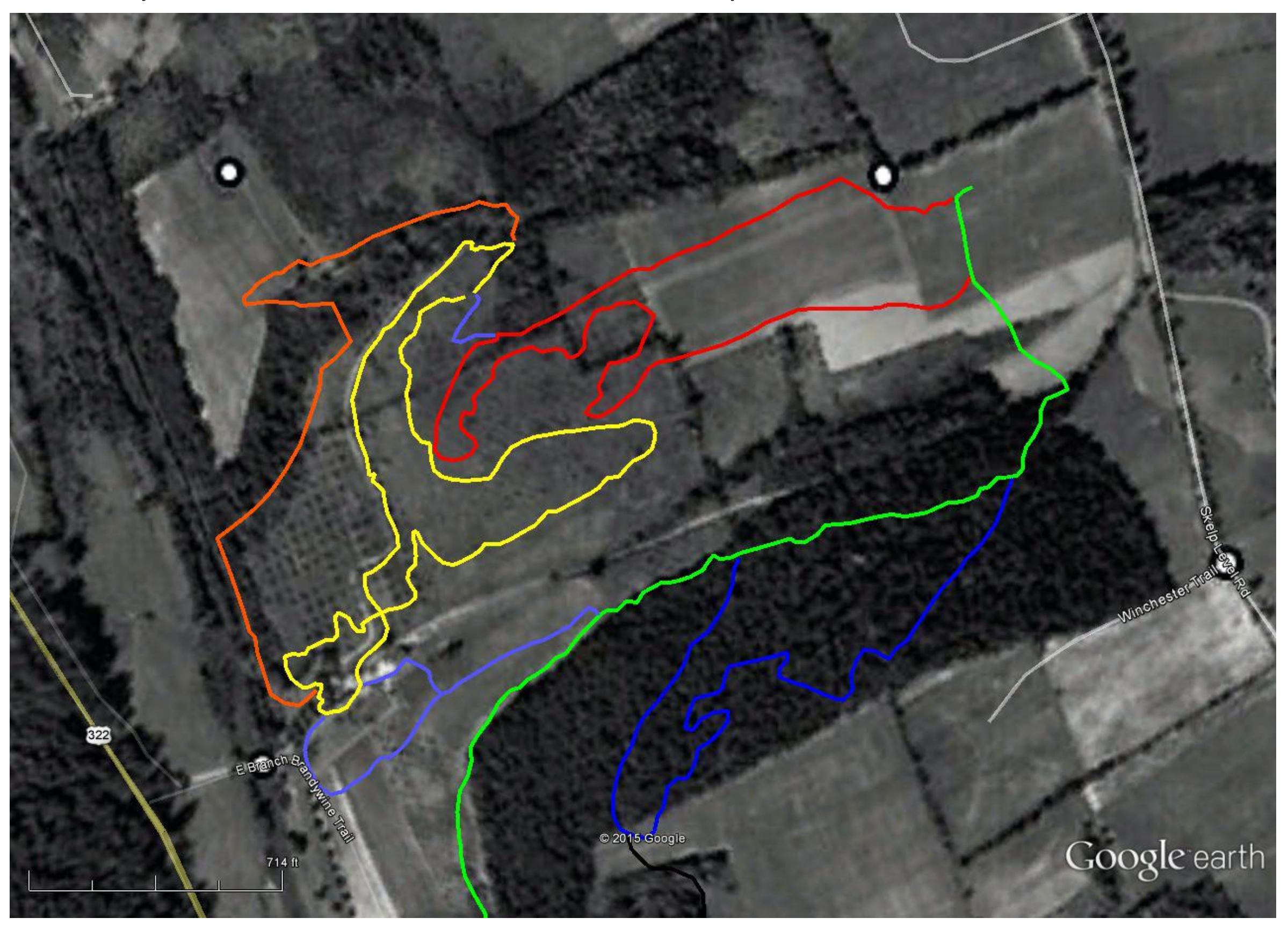




\section{Preparation - The Watershed System}

\section{StreamStats Report for Fulshaw Craeg walk, November 2017}

Region ID:

Workspace ID:

Clicked Point (Latitude, Longitude):

Time:

$+$
PA

PA20180311183744557000

$40.33998,-75.41876$

2018-03-11 14:38:00 -0400

\begin{tabular}{|l|r|l|}
\hline \multicolumn{3}{|c|}{ Basin Characteristics } \\
\hline \multicolumn{1}{|c|}{ Parameter Description } & Value & \multicolumn{1}{c|}{ Unit } \\
\hline Area that drains to a point on a stream & 8.86 & square miles \\
\hline Percentage of area of carbonate rock & 0 & percent \\
\hline Percentage of basin with urban development & 2 & percent \\
\hline Mean basin slope measured in degrees & 3 & degrees \\
\hline Depth to rock & 4.9 & feet \\
\hline Mean Basin Elevation & 493 & feet \\
\hline Mean Annual Precipitation & 45 & inches \\
\hline Percentage of area covered by forest & 83 & percent \\
\hline Mean Annual Flow & 13.9 & $\mathrm{ft}^{3} / \mathrm{s}$ \\
\hline 100 Year Peak Flood & 4290 & $\mathrm{ft}^{3} / \mathrm{s}$ \\
\hline 7 Day 10 Year Low Flow & 0.49 & $\mathrm{ft}^{3} / \mathrm{s}$ \\
\hline
\end{tabular}




\section{Preparation - The Watershed System}

How best to convey to participants:

- the very large amounts of material moving

- the interdependence of landscape topography and stream water chemistry

\begin{tabular}{|c|c|c|c|c|c|c|c|}
\hline 2 & A & $\mathrm{B}$ & $\mathrm{C}$ & $\mathrm{D}$ & $\mathrm{H}$ & I & $\mathrm{J}$ \\
\hline 1 & & \multicolumn{2}{|c|}{ Flux calculator } & & & & \\
\hline 2 & Chal & any of the valu & es in green & & & & \\
\hline 3 & & \multicolumn{6}{|c|}{ 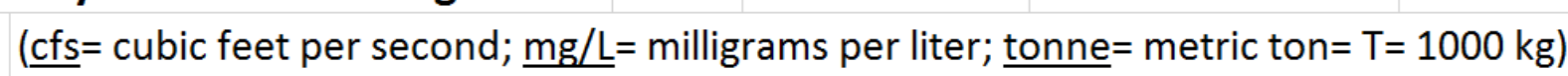 } \\
\hline 4 & & \multicolumn{6}{|c|}{$\underline{\mathrm{lbs}}=$ pounds; $\underline{\text { tons }}=2000 \mathrm{lbs}$} \\
\hline \multicolumn{8}{|c|}{ - P } \\
\hline 6 & & Flow & & & & & \\
\hline 7 & & \multicolumn{2}{|c|}{$13.9 \mathrm{cfs}$} & & & & \\
\hline 8 & & & & & \multicolumn{2}{|c|}{ Area in sq. mi. } & \\
\hline 9 & & \multicolumn{2}{|c|}{\begin{tabular}{|l|l|} 
Concentration & \\
\end{tabular}} & & Area & & \\
\hline 10 & & \multicolumn{2}{|c|}{$200.0 \mathrm{mg} / \mathrm{L}(\approx \mathrm{ppm})$} & & \multicolumn{2}{|c|}{8.9 sq. mi. } & \\
\hline \multicolumn{8}{|c|}{ - } \\
\hline 12 & & Flux & & & Area flux & & \\
\hline 13 & & 4.7 & $\mathrm{~kg} / \mathrm{min}$ & & 0.76 & tonne/(mi ${ }^{2}$ day $)$ & \\
\hline 14 & & 6.8 & tonne/day & & 279.1 & tonne/(mi ${ }^{2}$ year $)$ & \\
\hline 15 & & 2.5 & kT/year & & 107.8 & $\mathrm{~g} /\left(\mathrm{m}^{2}\right.$ year $)$ & \\
\hline 16 & & 10.4 & $\mathrm{Ibs} / \mathrm{min}$ & & 0.84 & tons $/\left(\mathrm{mi}^{2}\right.$ day $)$ & \\
\hline
\end{tabular}

This is part of the handout provided to participants

As you see $\mathrm{E}$. Branch Brandywine Creek today, 8 November 2015, water is flowing at about

- 48 cubic feet per second, or

- 21500 gallons per minute.

Chemicals (ions) dissolved in the water from rock weathering are moving at

- 0.8 pounds per second, or

- 48.5 pounds per minute, or

- 1.45 tons per hour, or

- 35 tons per day. 


\section{ThE WALK!}

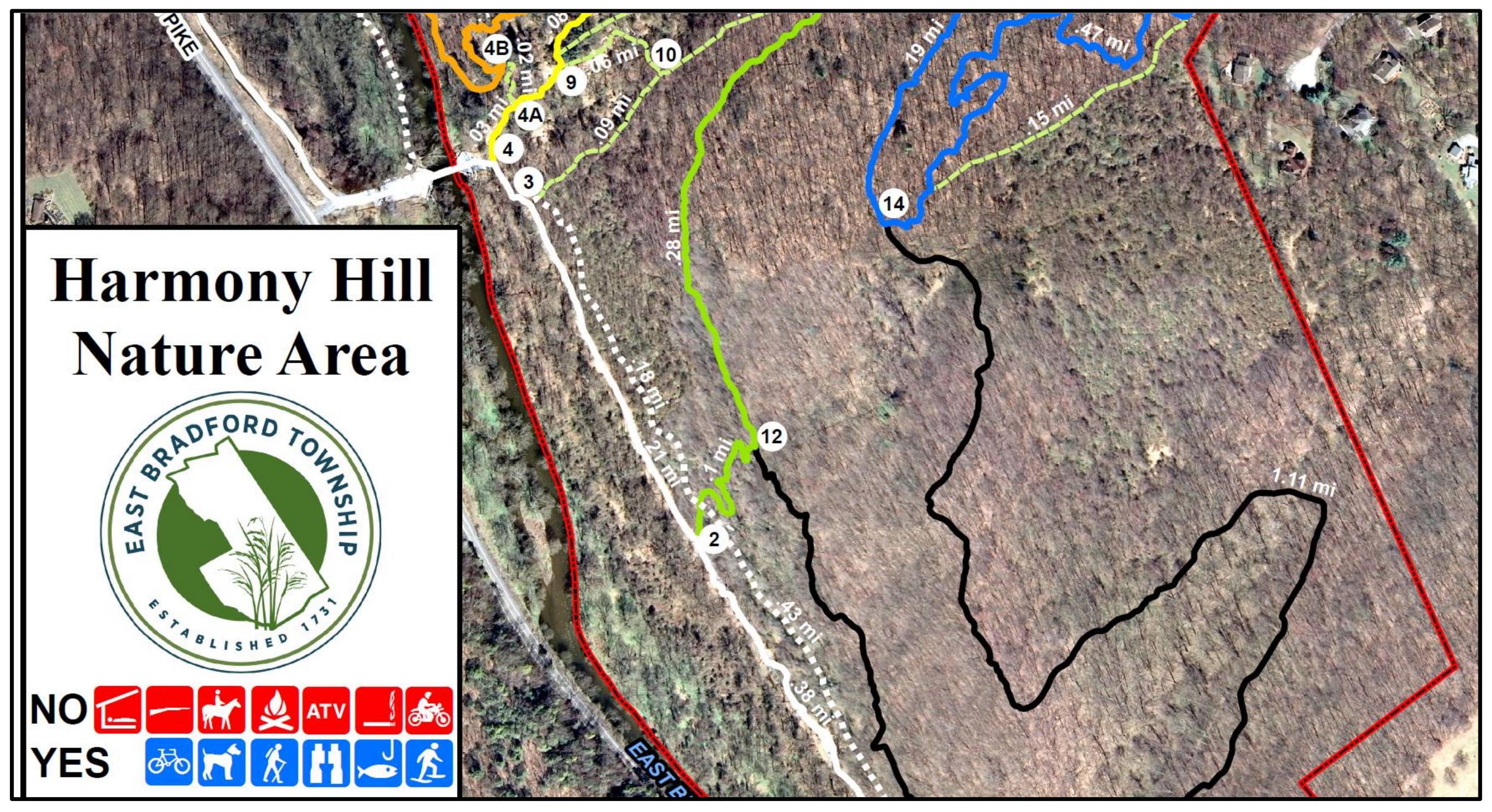


THE WALK

\section{BEGINS}

LOOK UP!

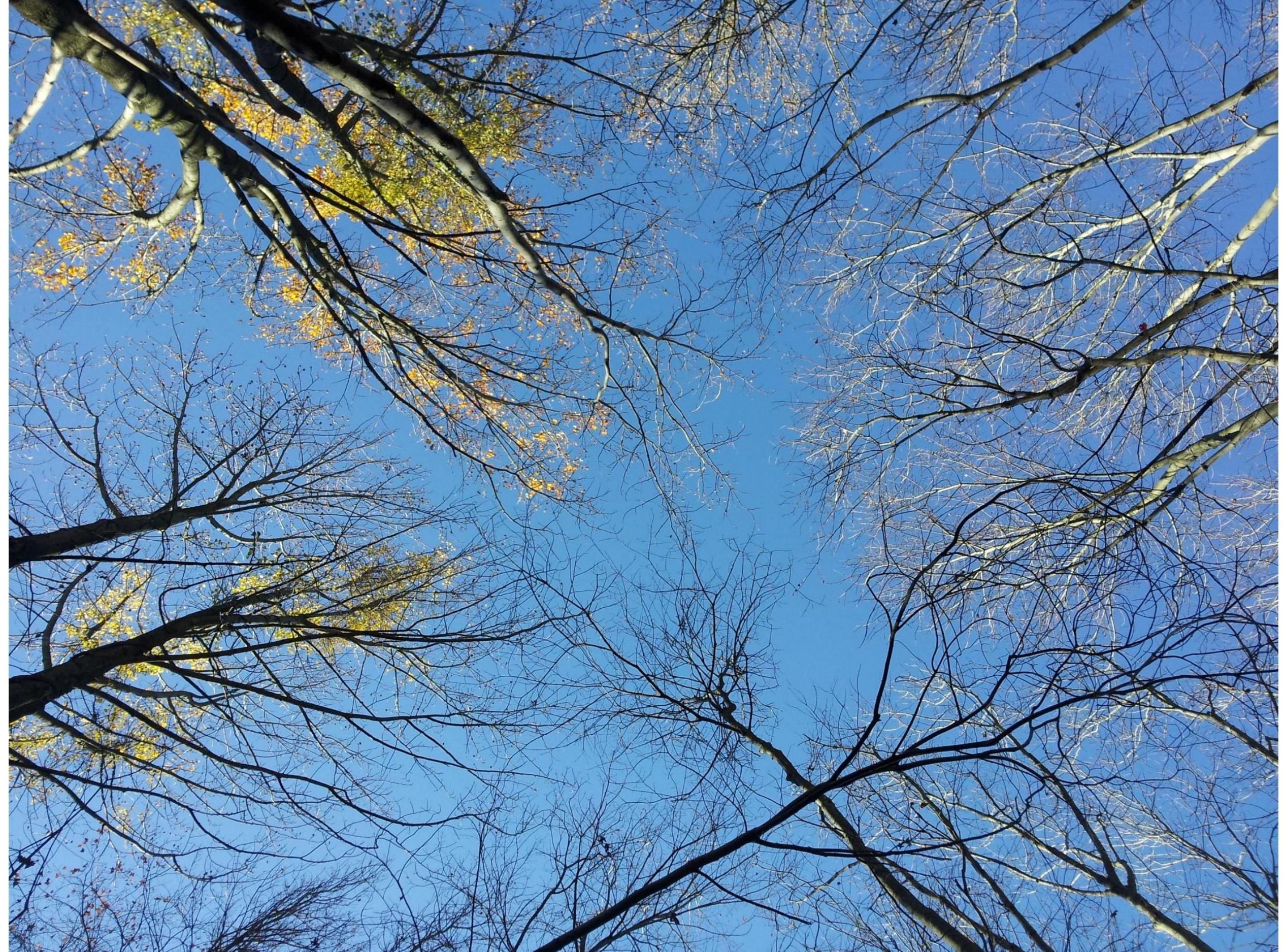




\section{THE WALK}

\section{BEGINS}

THINK BIG!

Using graphical handouts to help participants connect the surrounding landscape to large-scale processes

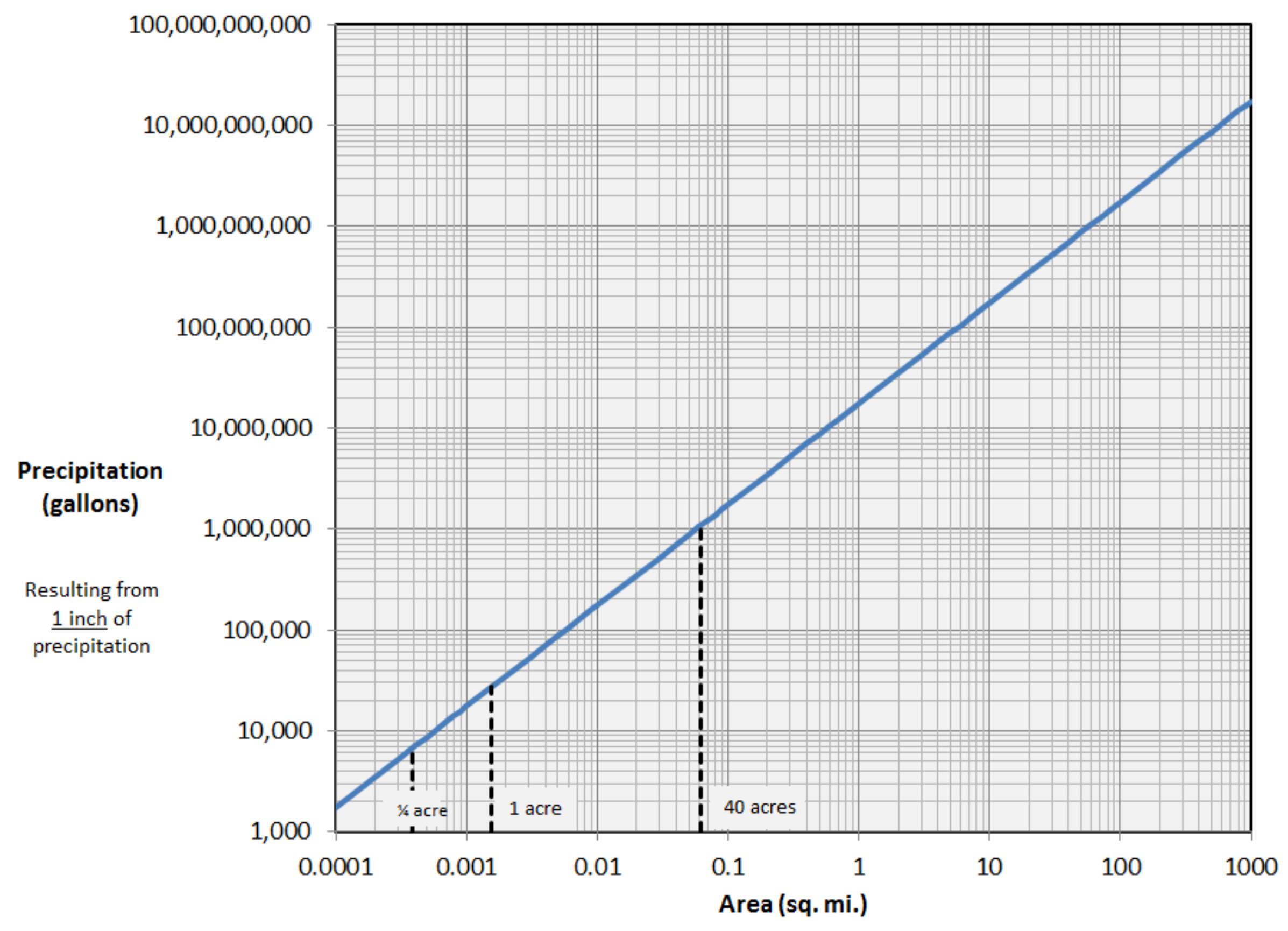




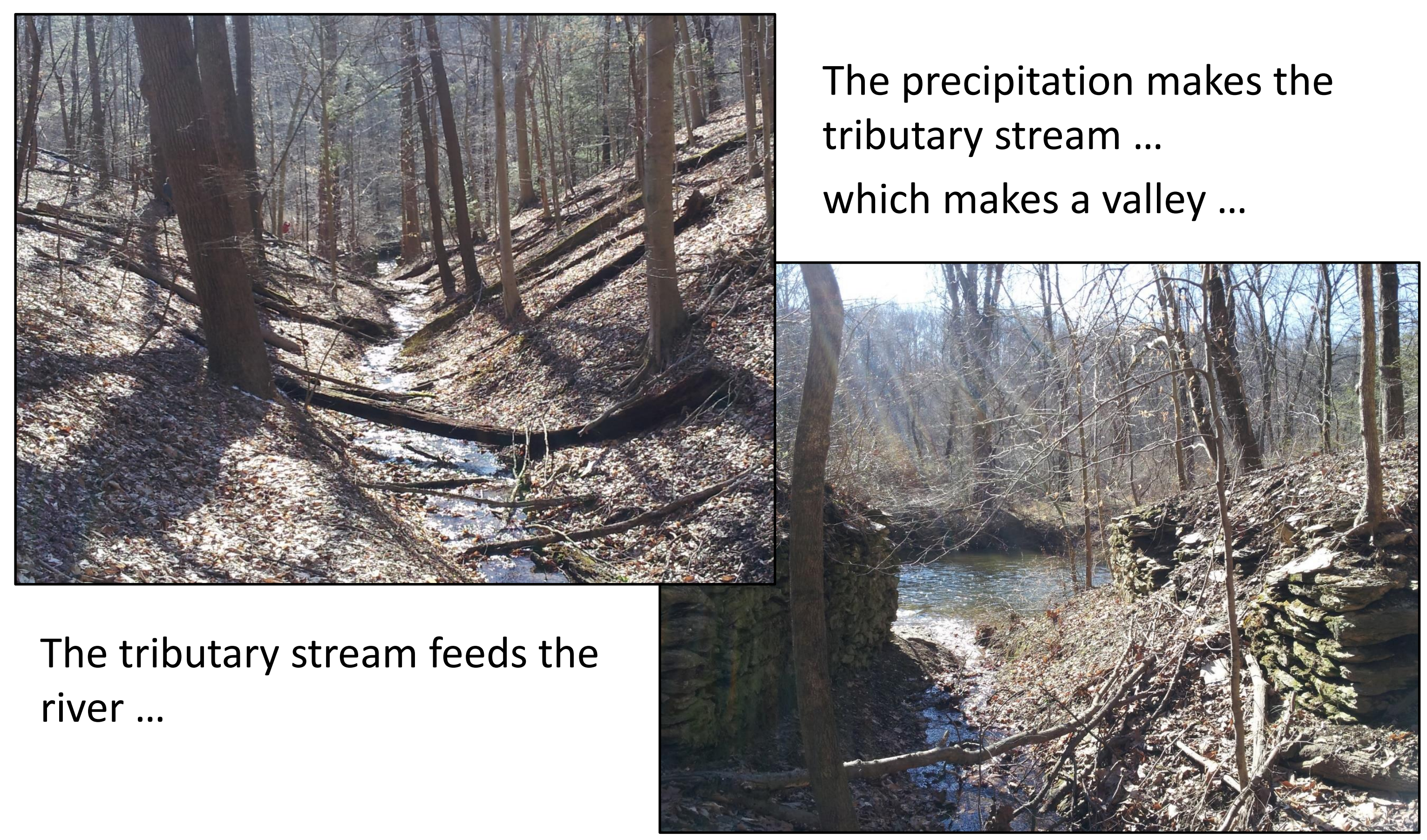


And vegetation is linked (by transpiration) to precipitation and stream flow

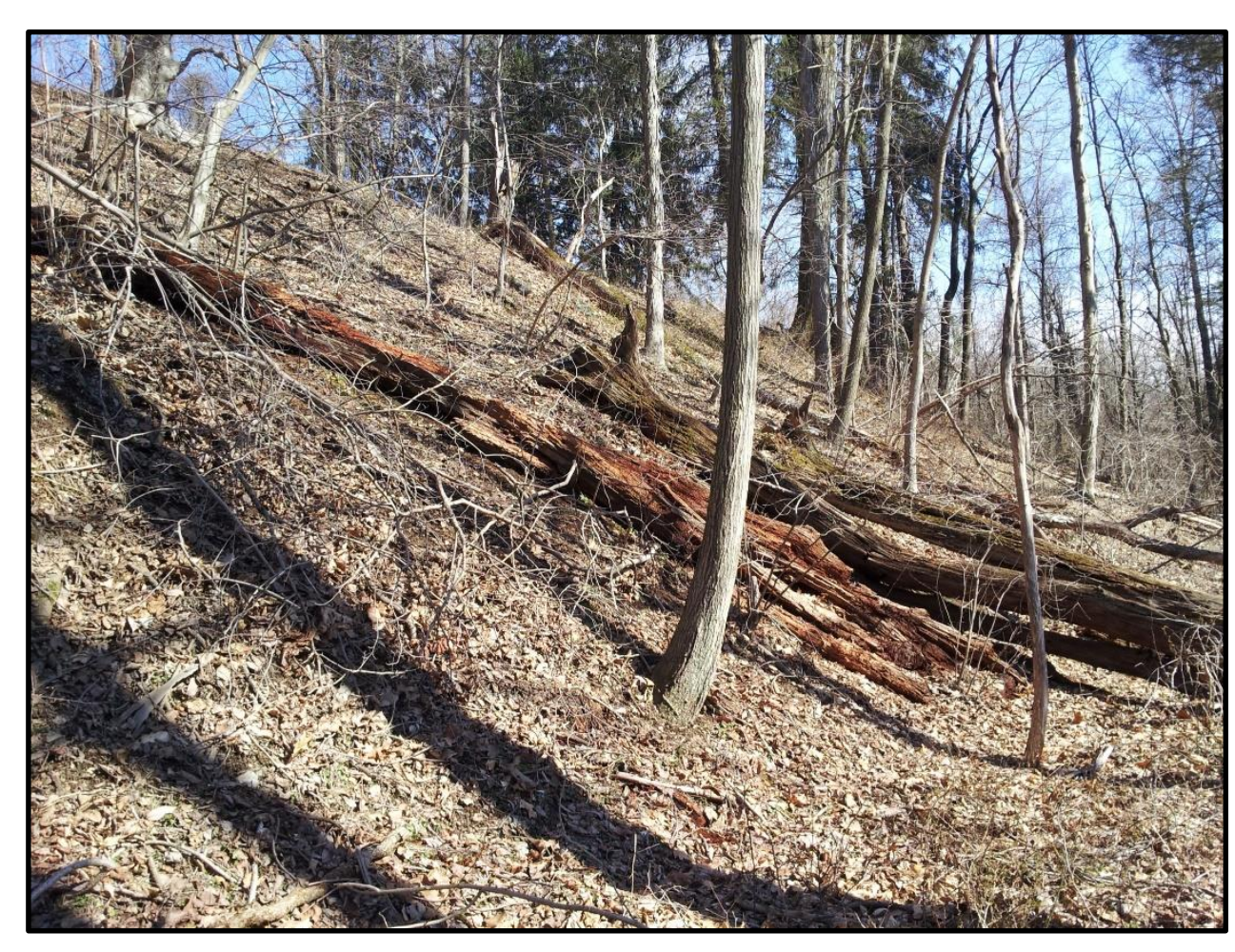

Flow of stream compared with precipitation

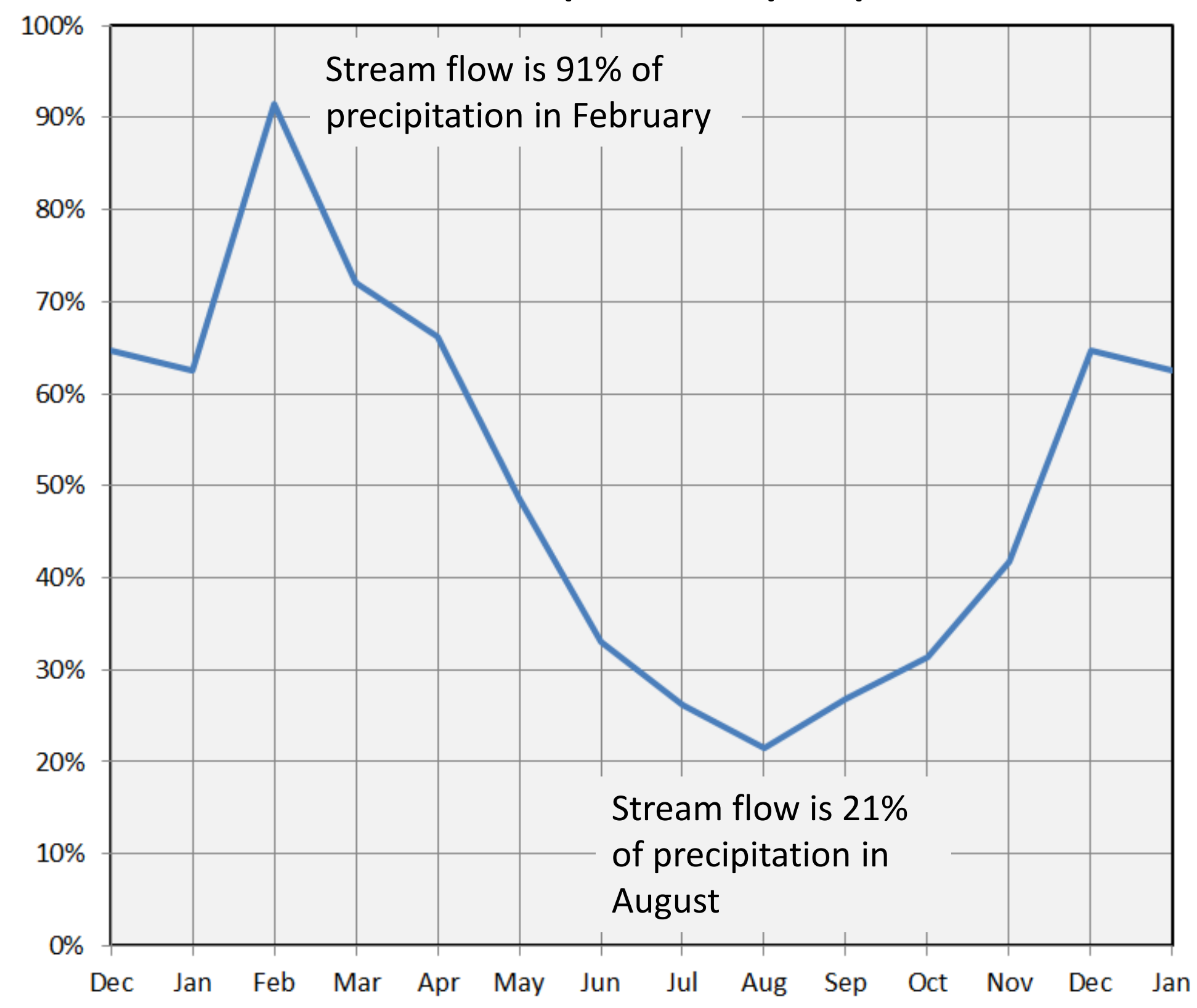




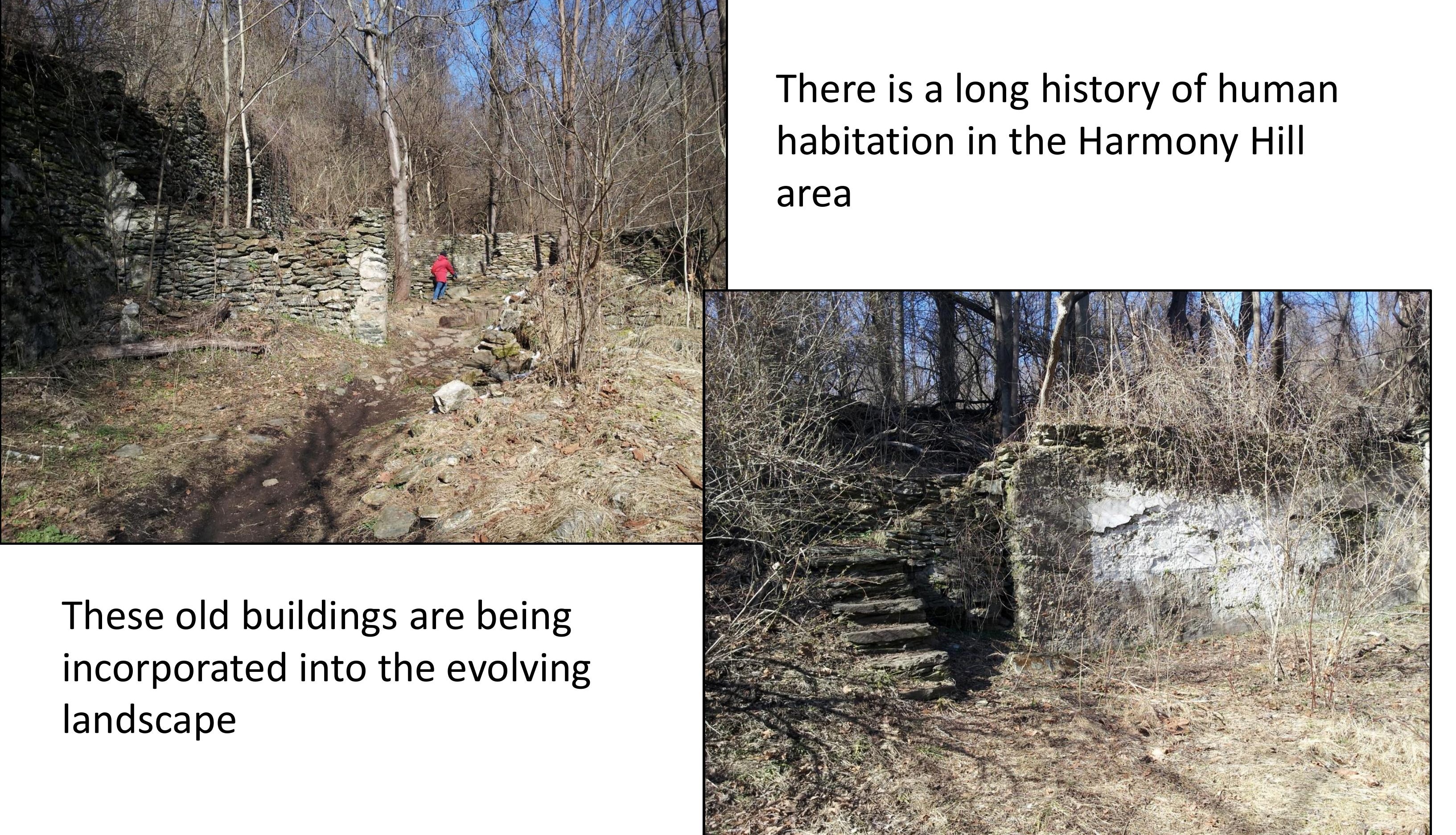


This is a re-growth forest very different from the indigenous forest

Forest and atmosphere are linked through photosynthesis, respiration, and decomposition

Overall increase in carbon dioxide due to human activities

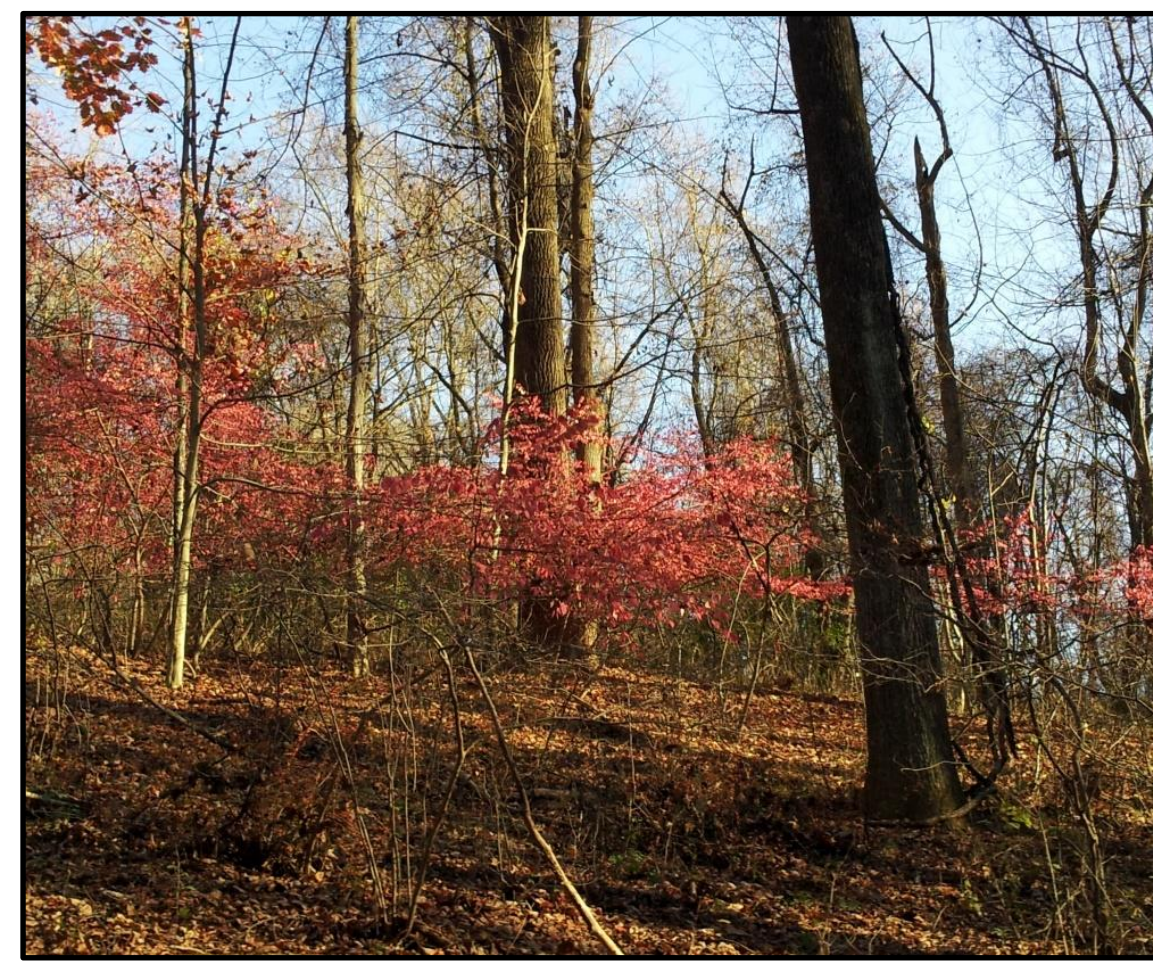

The Carbon Cycle graph was provided to visualize human change to the Earth System at a global scale

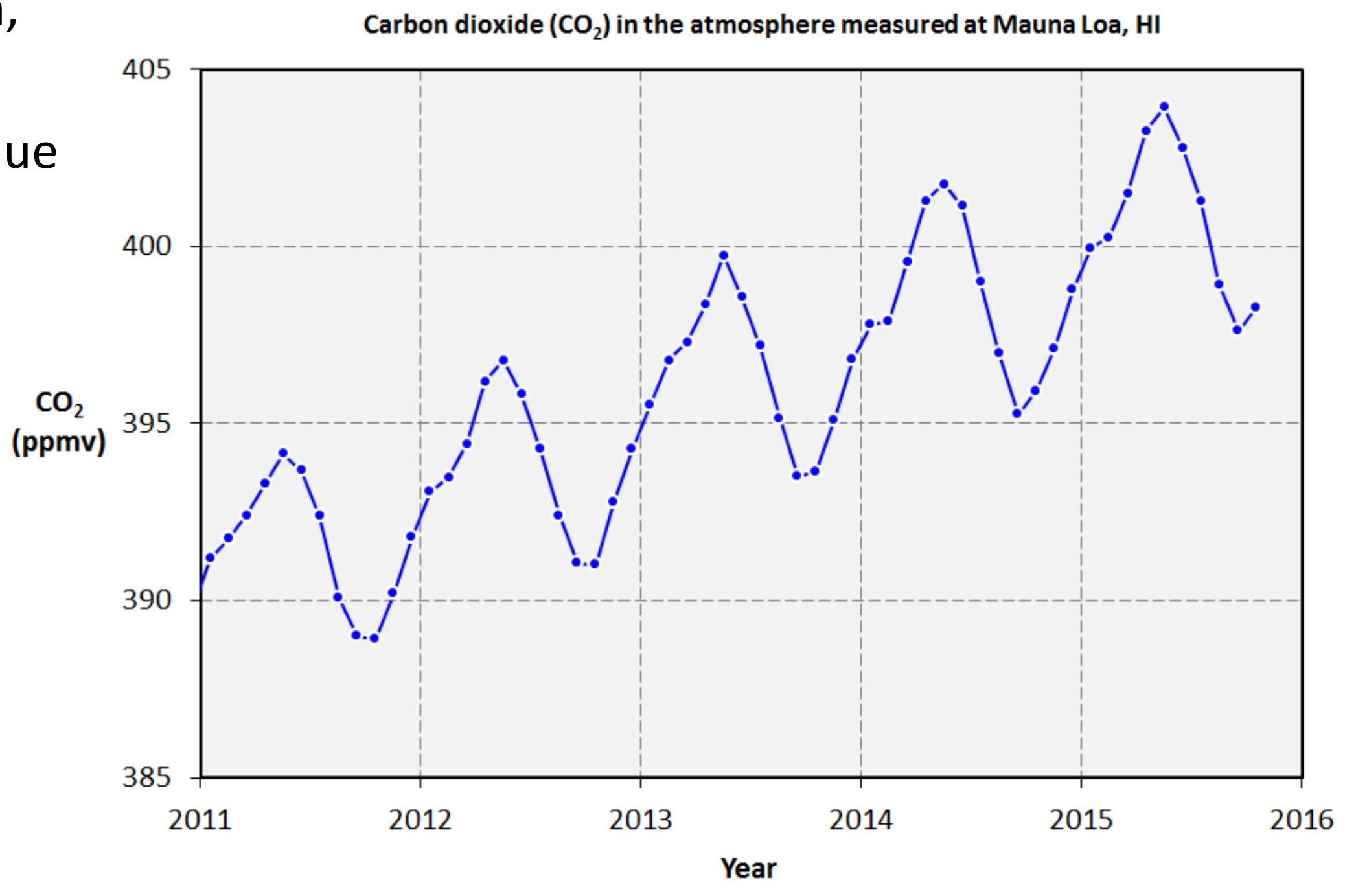


The Walk

\section{DRAWS TO A}

Close

TIME TRAVEL

Introducing participants to the pre-human geologic history of Harmony Hill

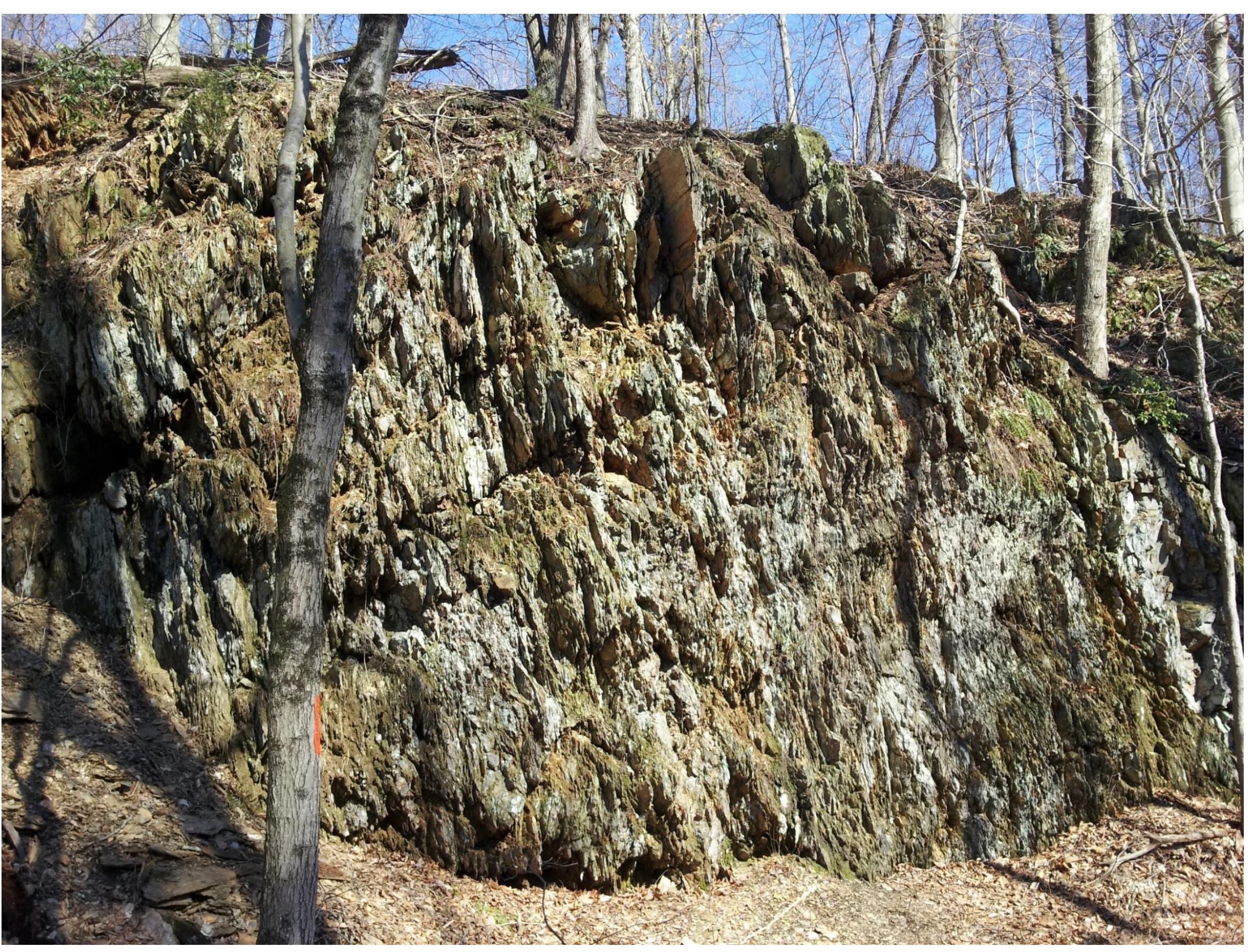




\section{The WALK!}

Natural
Lands visit what we do ev

\section{Geology Rocks! - SOLD OUT}

Fulshaw Craeg Preserve I Sat, November 04, 2017, 9:00am 11:00am

\section{Fulshaw Craeg Preserve}

\author{
Stewardship Plan
}

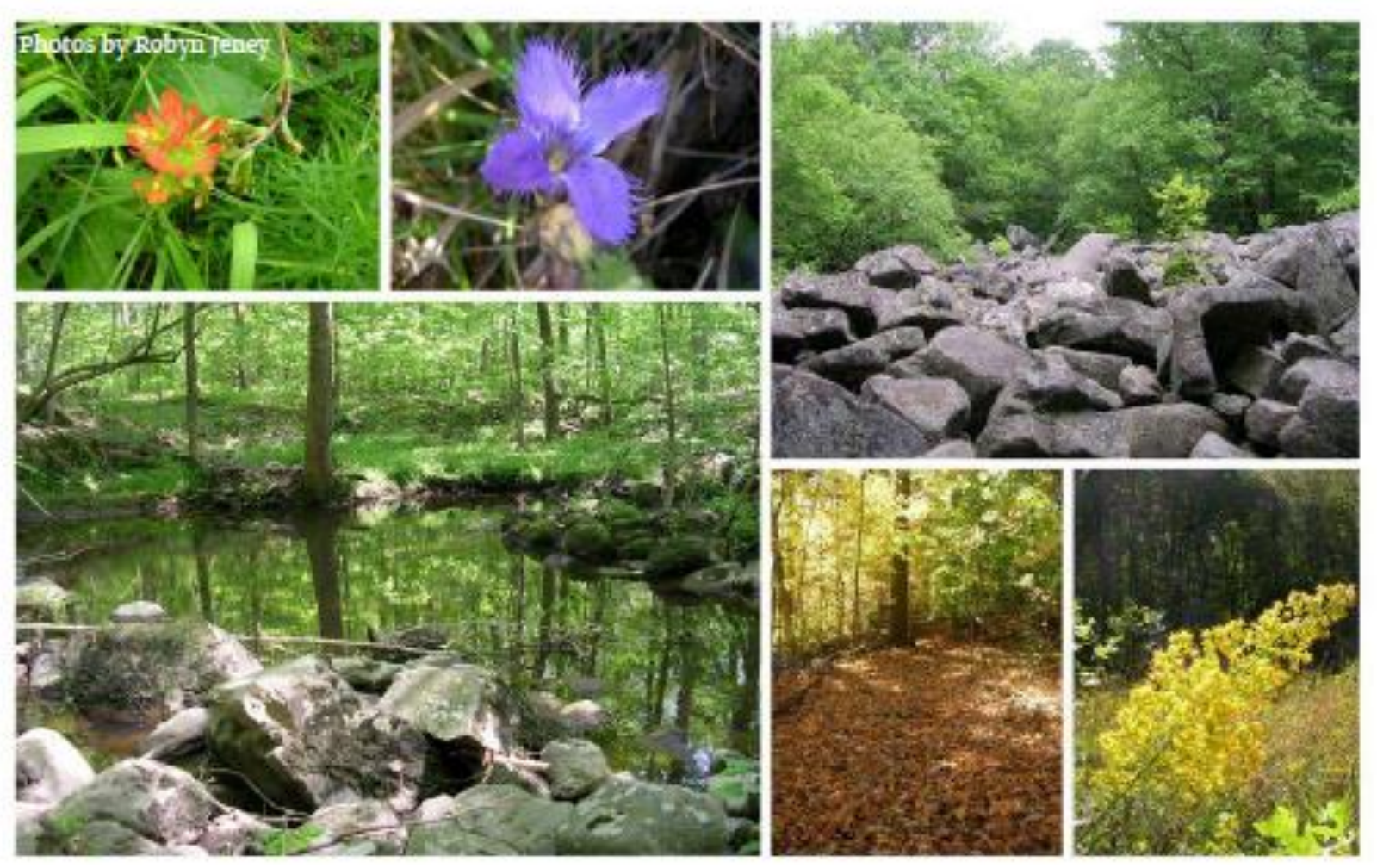

Montgomery County, PA 
The Walk Begins - Time Travel

Stand and look around and imagine traveling back in time

Introducing the Geologic Map

- Useful

- Easy to comprehend

- Beautiful!

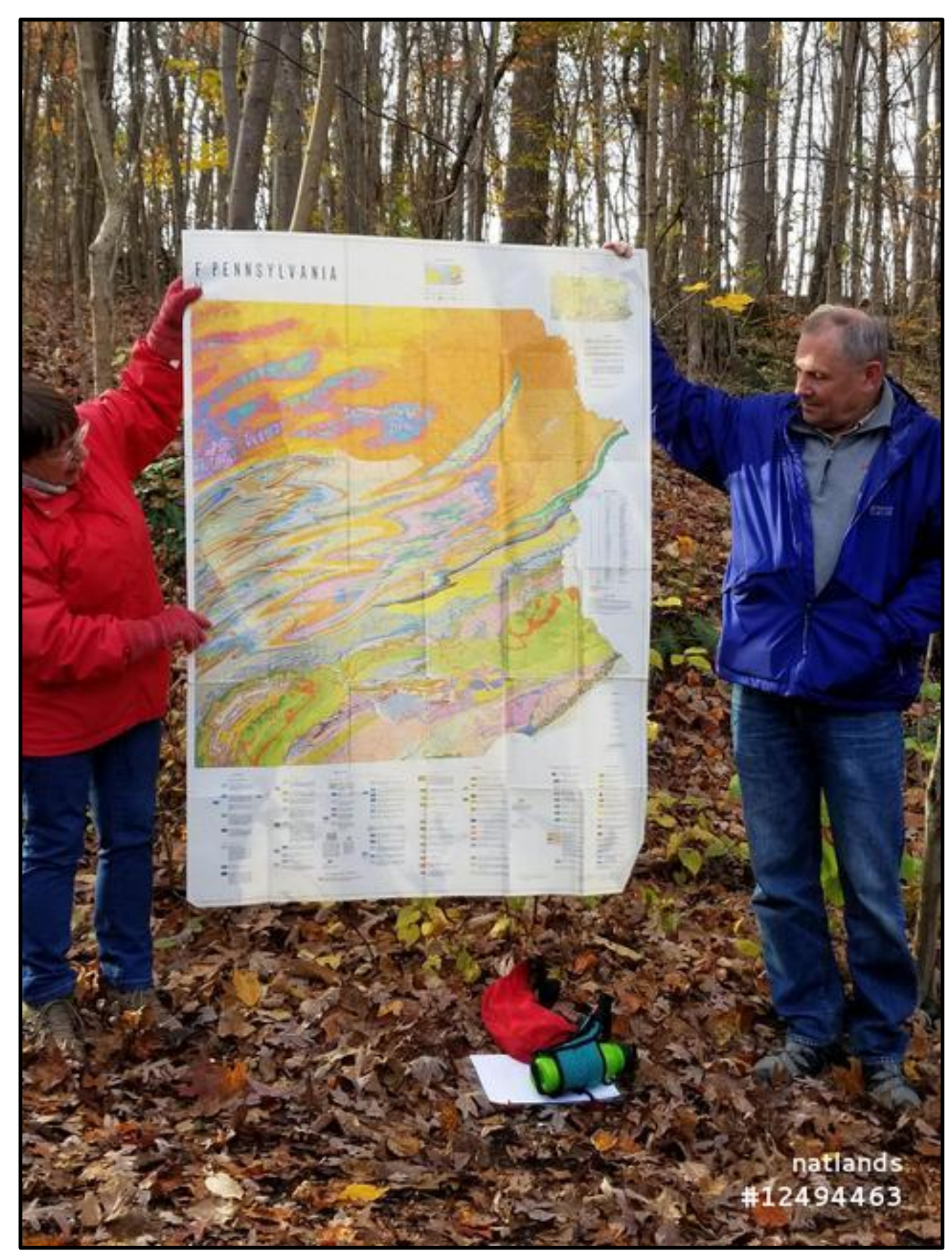


TIME TRAVEL

Go back 200 million years to a magma chamber 4 kilometers underground

Move forward in time to this day standing together in the preserve

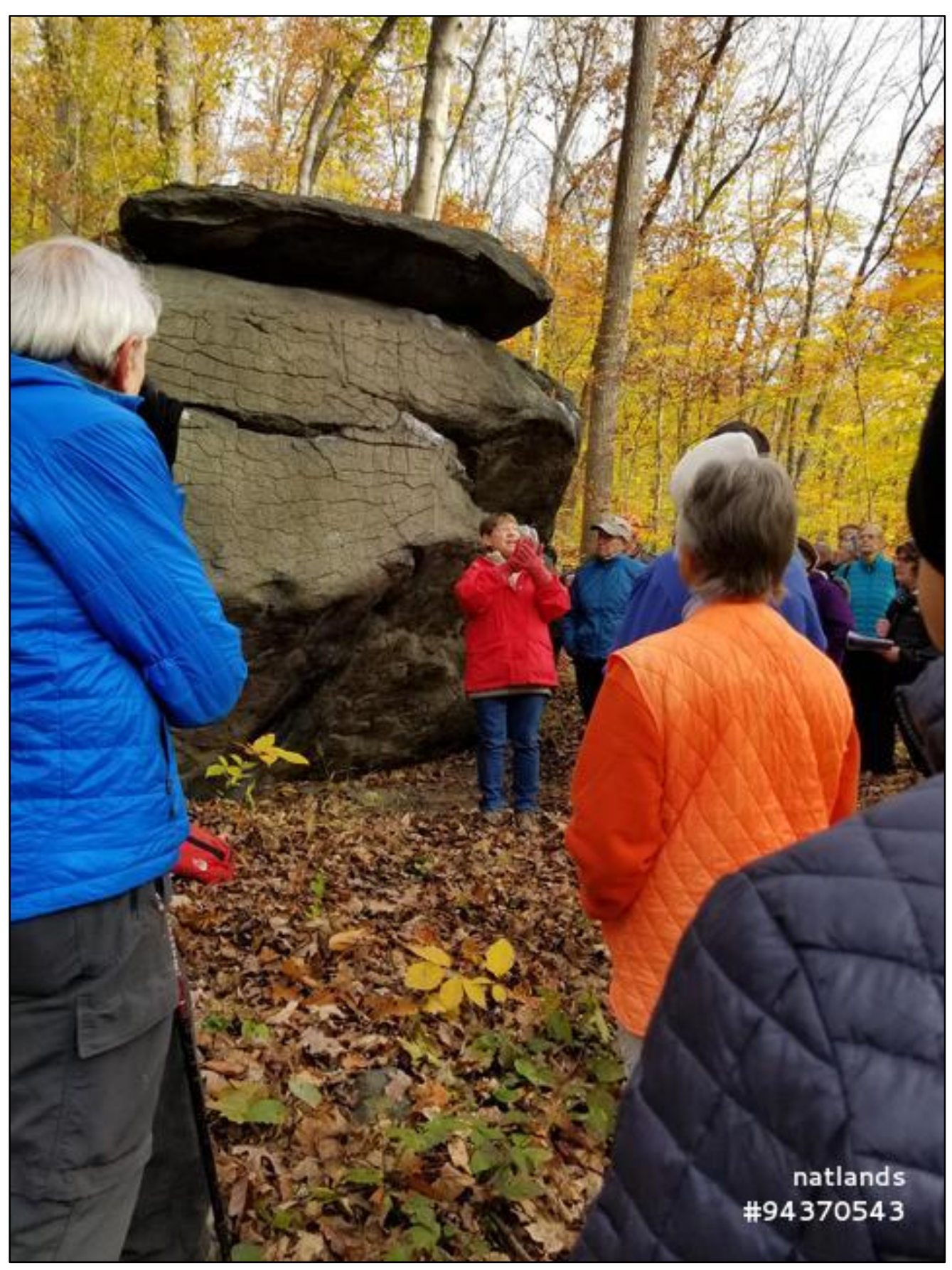


The landscape is the focus of attention
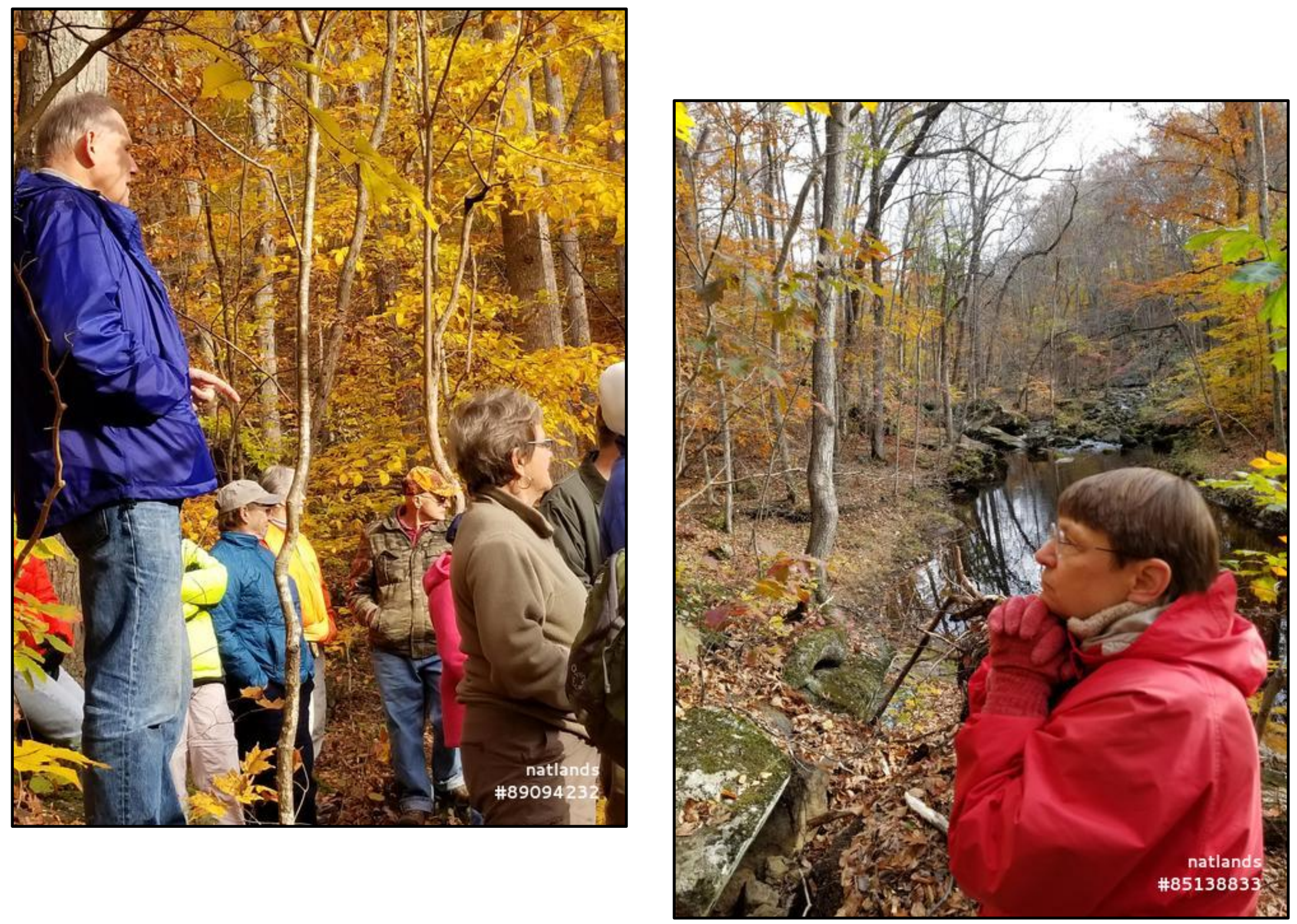
Drawing on experience, expertise, and sense of place of the participants

Ann F. Rhoads, Morris Arboretum, co-author of

The Plants of Pennsylvania: An Illustrated Guide and

Trees of Pennsylvania: A Complete Reference Guide.

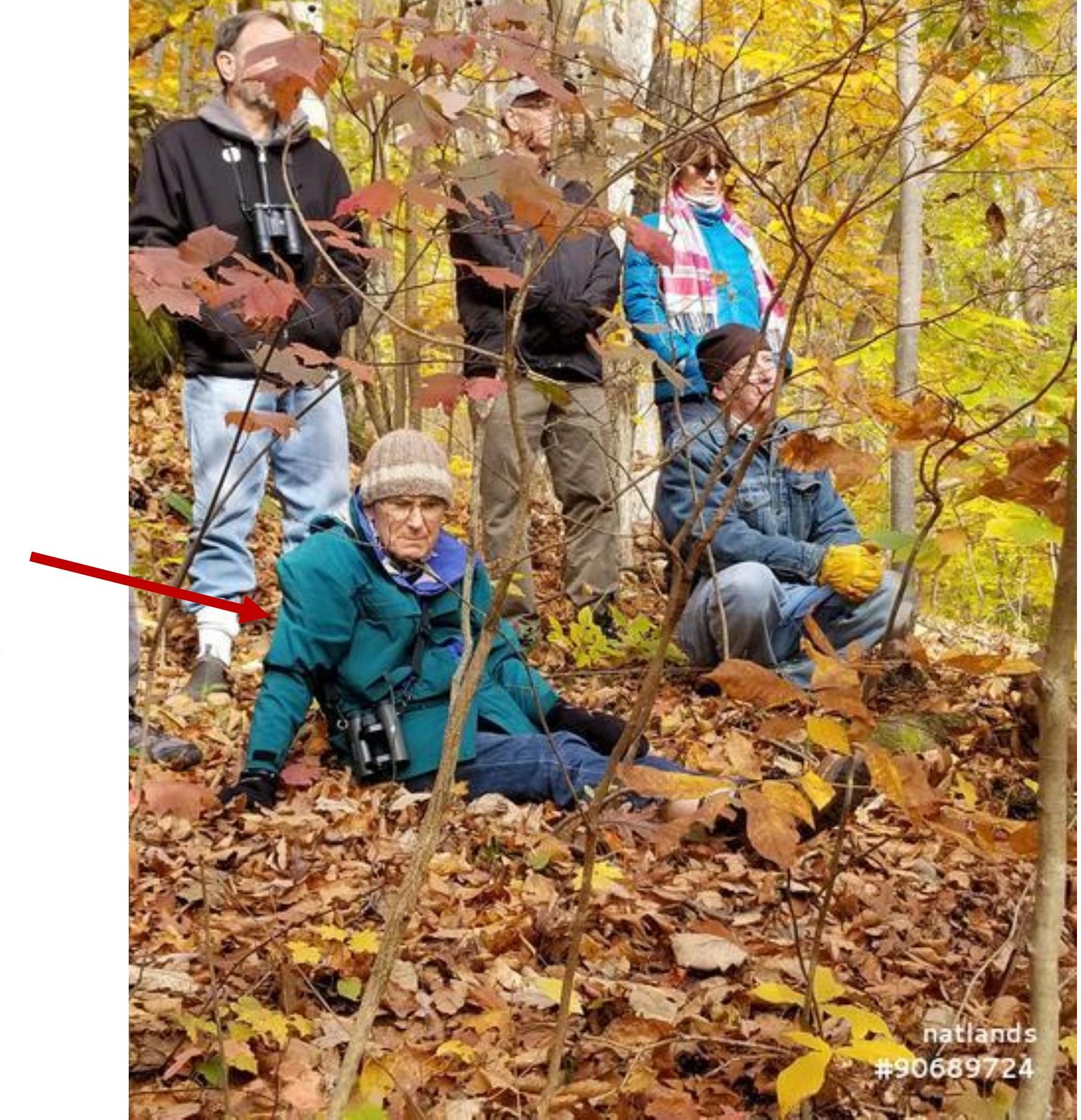




\section{The Walk EndS}

RINGING ROCKS AT LAST!

What makes the rocks ring?

Engaging participants to explore possible answers

A community of curious travelers connecting with the landscape

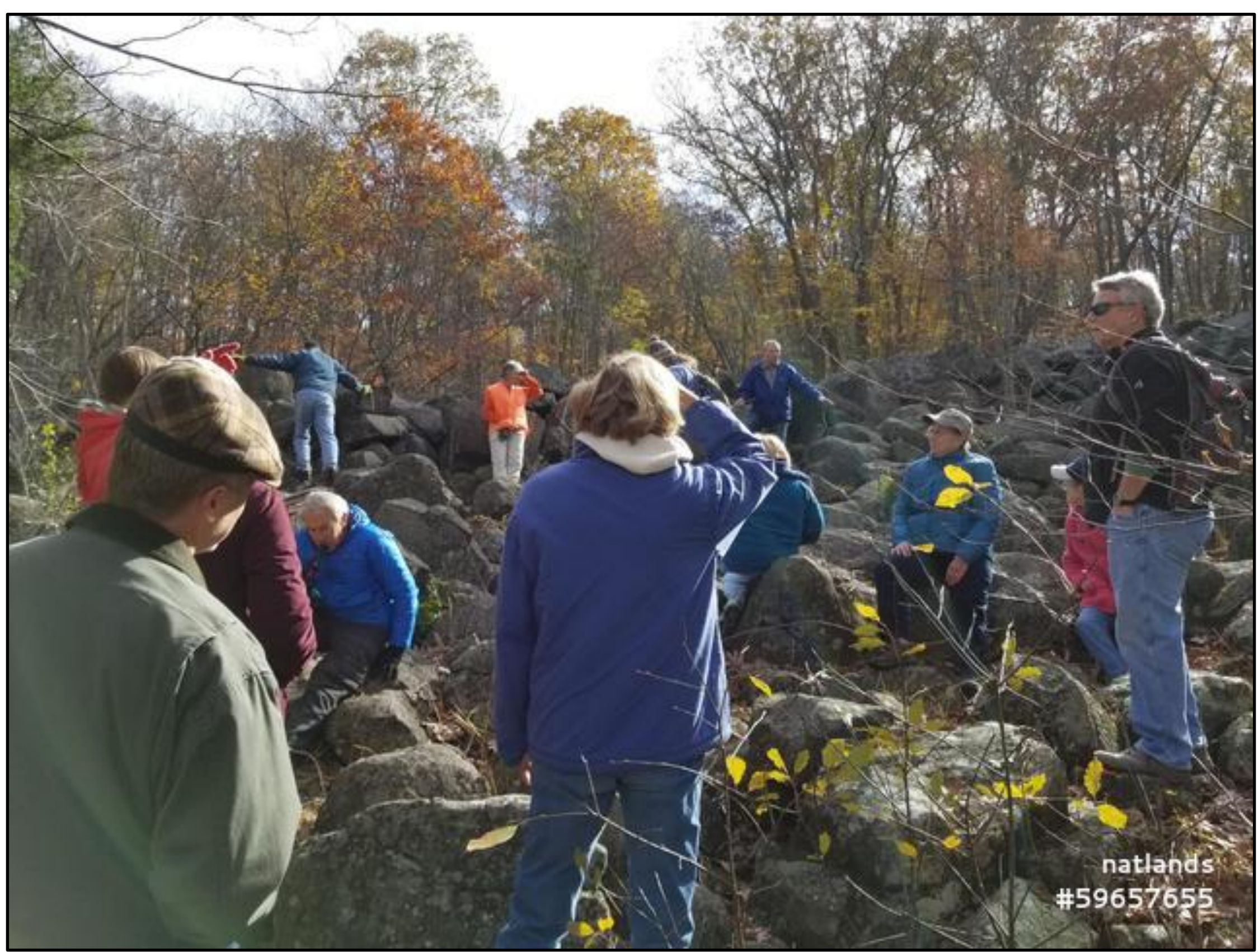




\section{thank you.}

Natural Vila Lands

...for joining Natural Lands on a beautiful morning geology walk at the boulder strewn Fulshaw Craeg Preserve.

Special thanks to Dr. LeeAnn Srogi and Dr. Tim Lutz for guiding an interesting and enlightening walk. Natural Lands' Fulshaw Craeg Preserve features an array of geological wonders, including steep, rocky slopes and a winding stream. These natural characteristics limited agriculture and development, leaving this land virtually

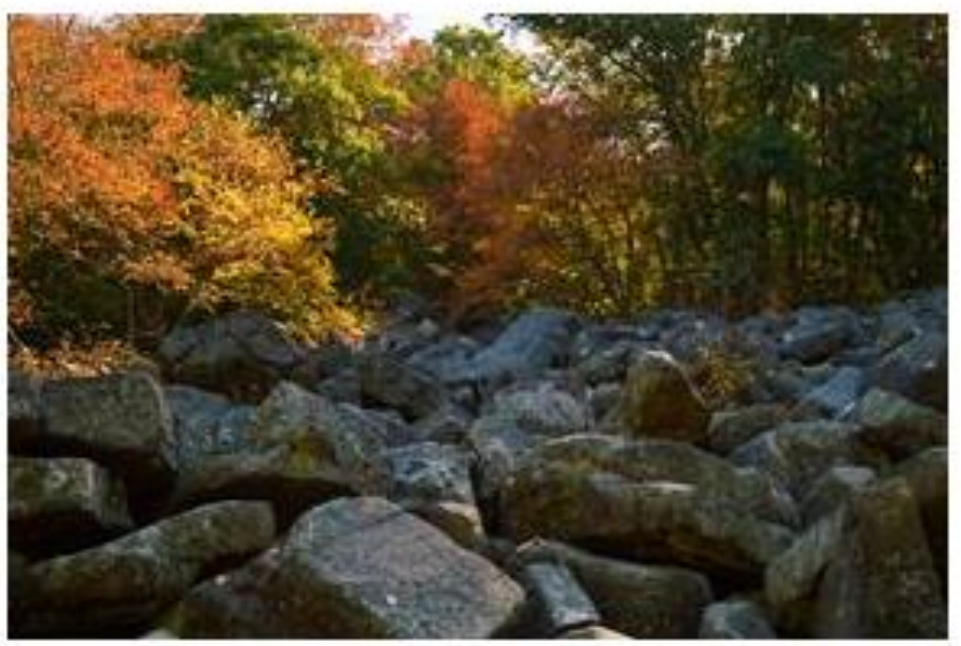

Thanks to Mandy Cantlin at East Bradford Township, PA, and Martha Moore and volunteers at Natural Lands unmarred by humans. From the informative introduction to the ringing of the boulders, we enjoyed a wonderful geological experience at the preserve!

Thanks to our Force of Nature volunteers for dedicated event assistance. 